\title{
On the origin of amniotic stem cells: of mice and men
}

\author{
MARIYA P. DOBREVA ${ }^{1,2}$, PAULO N. G. PEREIRA $^{1,2}$, JAN DEPREST $^{3}$ and AN ZWIJSEN ${ }^{*, 1,2}$ \\ ${ }^{1}$ Laboratory of Developmental Signaling, Department of Molecular and Developmental Genetics, VIB, \\ ${ }^{2}$ Center for Human Genetics, K.U. Leuven and ${ }^{3}$ Department of Obstetrics and Gynaecology, Fetal Medicine \\ Unit, University Hospital Gasthuisberg, Leuven, Belgium
}

\begin{abstract}
A common characteristic of mammals is the development of extraembryonic supporting tissues and organs that are required for embryonic implantation, survival and development in utero. The amnion is the innermost extraembryonic membrane that eventually surrounds the fetus of amniotes, and contains the amniotic fluid. Next to its function in in utero development, the amnion has been shown to have an important potential for clinical applications. It is mainly used as a dressing to stimulate healing in skin and ocular wounds. Moreover, cells derived from the amniotic membrane and amniotic fluid have been reported to possess stem cell features, like pluripotent differentiation ability. Little is known about the early development of this membrane in humans. The mouse is a powerful genetic model organism that can be used to address the dynamics and the developmental origin of amnion and amnion-derived stem cells. Here, we discuss some fundamental differences in amnion development in the disc-shaped primate embryo and in the cup-shaped mouse embryo. We emphasize the consequences that this may have on the derivation of amniotic "stem" cells. After revision of the different isolation procedures of amniotic (fluid) derived "stem" cells from rodents, we reveal striking differences in the sources used to derive these cells across studies. The profound differences in the development of the extraembryonic membranes and cavities between primates and rodents may result in comparing cell types of different developmental origins, eventually leading to missinterpretations.
\end{abstract}

KEY WORDS: amnion, epiblast, gastrulation, stem cell

\section{Introduction}

\section{Architecture and function of the amnion}

During gestation, the amnion has been ascribed to function as its Greek name suggests - as a membranous sac that contains the conceptus and the amniotic fluid. In primates, including human, it is an adjustable bio-container that provides the fetus a limited space to allow movements. It functions as a filter and preventive shock absorber that protects against ascending infections, traumas and toxins (Calvin and Oyen, 2007; Schmidt, 1992). Resistance to rupture or tearing of fetal membranes is provided almost exclusively by the collagen present in the basement membrane of the amnion. The amnion is a metabolically active membrane that is involved in solute and water maintaining amniotic fluid homeostasis. The amniotic membrane secretes nutritious factors (Beddington and Robertson, 1999; Chambers et al., 2003; Enders et al., 1986) and suppresses the semiallogenic immune response against the fetus (Benirschke and Kaufmann, 1995; Bryant-Greenwood, 1998; Calvin and Oyen, 2007).
In primates, the amnion and the other fetal membrane, the chorion, extend from the edge of the placenta. The amnion is contiguous with the umbilical cord and the fetal skin. Often considered as a part of the ephemeral organ placenta, the amniotic membrane consists of two spatial portions. The placental portion is thicker and contiguous to the chorionic plate, while

Abbreviations used in this paper: AEC, amniotic epithelial cell; AMC, amniotic mesenchymal cell; AM-hMSC, amniotic membrane-human mesenchymal stromal cell; AFC, amniotic fluid-derived cell; BM-hMSC, bone marrowhuman mesenchymal stromal cell; CD, cluster of differentiation; ECM, extracellular matrix; ESC, embryonic stem cell; FACS, fluorescence-activated cell sorting; HLA, human leukocyte antigen; LIF, leukaemia inhibitory factor; MAPC, multipotent adult progenitor cell; Oct-4, octamer-binding transcription factor 4; PPROM, preterm premature rupture of the membranes; iPROM, iatrogenic PROM; iPS cell, induced pluripotent cell; SCID, severe combined immunodeficiency; SCF, stem cell factor; SSEA, stage-specific embryonic antigen; TRA, tumor rejection antigen.

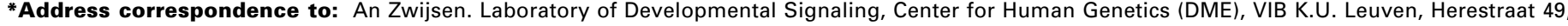
Onderwijs \& Navorsing 1, bus 812, B3000 Leuven, Belgium. Tel: +32-16-33-00-06. Fax: +32-16-345-916. e-mail: An.Zwijsen@cme.vib-kuleuven.be
} 
the fetal portion is enwrapping the fetus (Fig. 1 A,B) (Kobayashi et al., 2008a). A recent study reports that the seemingly homogeneous human amnion is biologically heterogeneous and compartmentalized (Han et al., 2008).

The thickness of the human term amnion varies between individuals and depends on the location of the sample (70 to 180 $\mu \mathrm{m}$ thick) (Benirschke and Kaufmann, 1995, Hasegawa et al., 2004), but it is remarkably strong and elastic. Amnion withstands the progressive stretching of the growing embryo, internal and external traumas, and fast and slow pressure changes. Its strength is due to the epithelial layer and the amniotic mesodermal derived connective tissue in which 4 layers can be distinguished (Bourne, 1966; Kobayashi et al., 2008a; van Herendael et al., 1978) (Fig. $1 \mathrm{C}, \mathrm{D})$. The epithelial monolayer is composed of flat, cuboidal and columnar cells in direct contact with the amniotic fluid. These cells secrete glycoproteins, collagens and laminins that constitute the basement membrane, which is in contact with the amniotic mesoderm (Takashima et al., 2008; van Herendael et al., 1978). A compact acellular layer can be distinguished next to the basement lamina that is made up of connective tissue forming collagen parallel bundles that maintain the mechanical integrity of the amnion. The fibroblast (stromal) layer is the thickest amniotic cell layer and contains fibroblast-like mesenchymal cells, referred to as amniotic mesenchymal (stromal) cells, and occasionally monocyte-like cells within collagenous extracellular matrix (ECM) (Kobayashi et al., 2008a; Magatti et al., 2008; van Herendael et al., 1978).

Fig. 1. Appearance of term fetal membranes in primates. Schematic representation of a human fetus within its extraembryonic membranes around 10-12 weeks (A) and 20 weeks (B) of gestation. The umbilical cord consists of extraembryonic mesoderm and endoderm. The endodermal component is not represented for simplicity. (C) Haematoxylin-eosin staining of a paraffin section of term amnion and chorion in the rhesus monkey (courtesy L. Lewi and $P$. Vandenbergh). (D) Schematic representation of the layering of human amnion and chorion. The structure of the membranes generally remains constant from the fourth month of pregnancy until term (Benirschke and Kaufmann 1995). Abbreviations:

AC, amniotic cavity; Am: amnion; Ch: chorion; EC: exocoelom, FA: fetal amnion; PA: placental amnion; PI: placenta; UC: umbilical cord; YS: yolk sac.

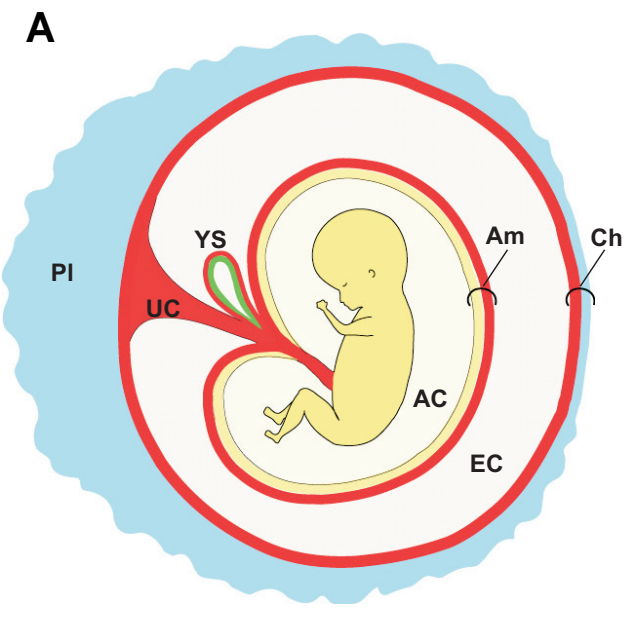

Embryonic (skin) and amniotic ectoderm

The intermediate (spongy) layer between amnion and chorion is highly variable in thickness. It consists of hydrated proteoglycans and glycoproteins that absorb water and swell, and of nonfibrillar collagen meshwork. This layer enables the amnion to slide over the chorion. The less tensile chorion is about four times thicker than the amnion and is composed of mesodermal and trophoblastic regions. Adjacent to the spongy layer is the reticular layer containing mesenchymal (stromal) cells within a fibronectin, collagen and fibrillin-rich ECM. Transmission electron microscopy findings reveal a considerable difference between amniotic and chorionic stromal cells. Amniotic stromal cells show phenotypic characteristics of both mesenchymal and epithelial cells. Chorionic cells, on the other hand, resemble hematopoietic progenitors (Pasquinelli et al., 2007; Sakuragawa et al., 2004). A basement membrane separates the chorionic mesoderm from the proliferating cytotrophoblastic cells which are dispersed within the fibrinoid (cytotrophoblastic) layer. This layer grows during pregnancy and it is the site where separation of the membranes occurs during

B

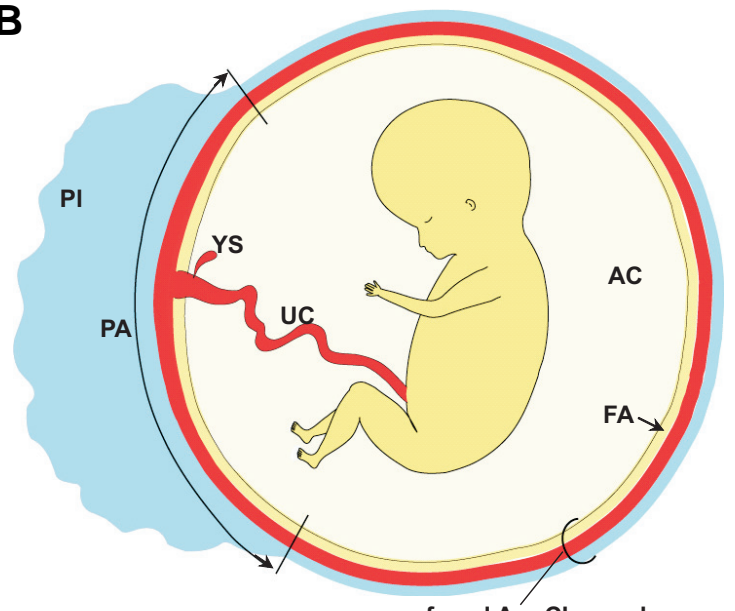

fused Am-Ch membrane

Trophoblast derivatives and maternal placenta
Extraembryonic endoderm
C D

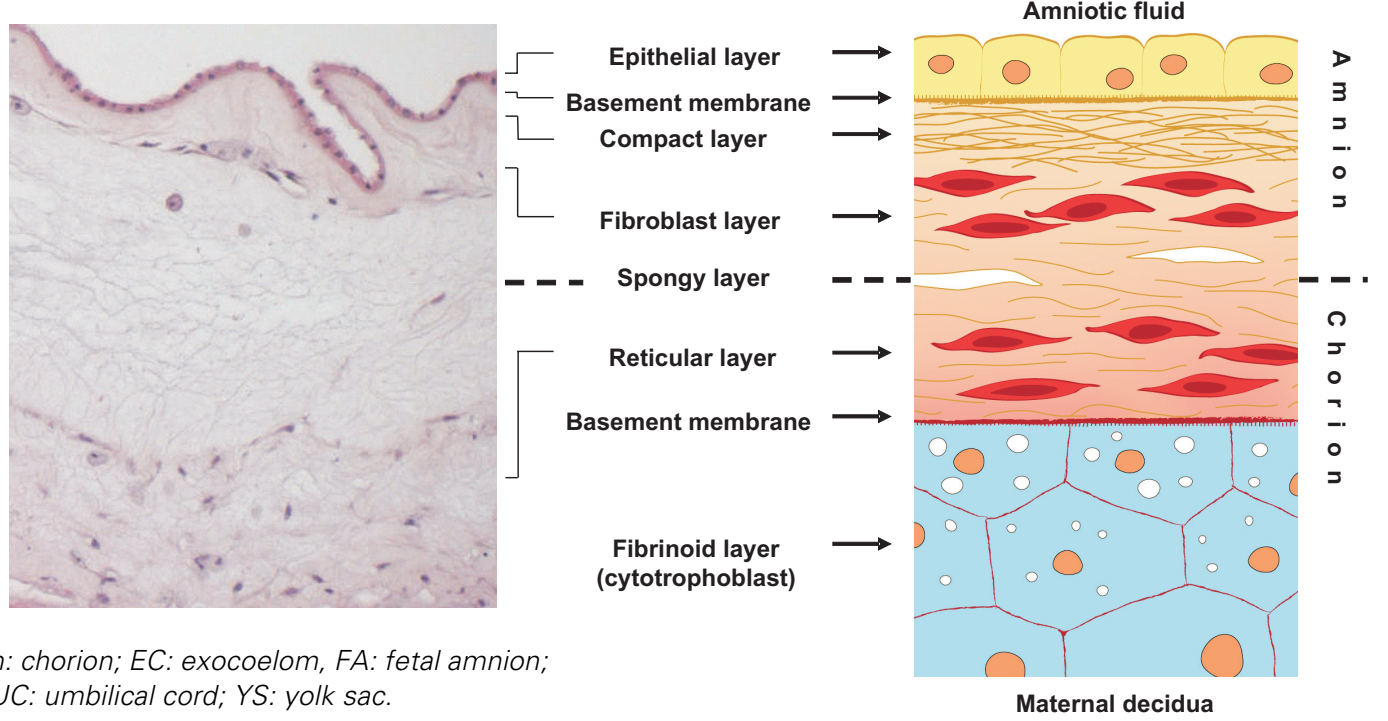


labour. The fibrinoid layer is in contact with the maternal decidua (Bourne, 1966; van Herendael et al., 1978). Chorionic mesoderm is vascularized from the beginning of the $2^{\text {nd }}$ trimester onwards (Benirschke and Kaufmann, 1995). Remarkably, in the vast majority of the amniotes, amnion is one of the very few tissues that has no vascularity. In humans, the chorion and the amniotic fluid transfer nutrients to the avascular amnion by diffusion.

At term, the physiological rupture of the amnion occurs in a controlled fashion at the zone of altered morphology within the rupture site (Malak and Bell, 1994). At that site, apoptosis of amniotic cells and the induction of a specific gelatinase (matrix metalloproteinase (MMP)-9) and collagenases lead to degradation of fibrillar collagen and precede labour (Lei et al., 1996; Lei et al., 1999). Spontaneous preterm premature rupture (PPROM) of the fetal membranes complicates 1 to $4 \%$ of the pregnancies. It usually leads to preterm labour, and it is probably due to multifactorial processes that may involve infection, but also genetic predisposition. The premature ruptures can be related to high expression levels of relaxins, low expression levels of ECM proteins synthesized by the fetal membranes, or to degradation of these proteins by induced MMPs and subsequent ECM remodelling (Artal et al., 1976; Bogic et al., 2000; Guller et al., 1995; Parry and Strauss, 1998; Xu et al., 2002). A complete different clinical entity and cause are membrane ruptures due to invasive procedures, e.g. endoscopic fetal surgery. This is typically referred to as iatrogenic PPROM or iPPROM, pointing to the circumscribed, surgical injury occurring to the membranes at the time of intervention. It has been shown that those trauma sites show little if no healing capacity (Gratacos et al., 2006). Because of the clinical relevance of its consequences, several groups have explored the possibility to treat or prevent iPPROM from happening by sealing the membrane defect. Most research now focuses on using matrices that may improve sealing and stimulate wound healing (Lewi et al., 2004; Mallik et al., 2007; Ochsenbein-Kolble et al., 2007).

\section{Clinical applications of human amnion}

Apart from its function during gestation, human amnion has a long-lasting history of clinical applications. It has been reported for the first time as a biological dressing to heal skin wounds a century ago (Davis, 1910). In management of open wounds the major goal is to obtain a clean and closed wound in the shortest time possible, thereby preventing fluid, heat and nutrient loss, as well as wound infection, pain and decreased mobility. As such, this can be a life-saving treatment (Gruss and Jirsch, 1978; Ravishanker et al., 2003). Shortly after its initial use, amnion was used in treatment of burn injuries (Sabella, 1913). The rationale of using amnion grafts was to provide permanent coverage of the defect, but this failed due to immunologic host response. Only in 1973 the use of human amniotic membrane as a temporary coverage of skin burns was evaluated by Robson and Krizek (Robson and Krizek, 1973, Robson et al., 1973). They showed that burn wound coverage by amnion significantly decreased the bacterial contamination in infected rats. Nowadays, amniotic membranes are efficiently used as allografts for treating skin burns; open and non-healing ulcers; pressure sores; and surgical, infected and traumatic wounds; as well as skin graft donor sites (Andonovska et al., 2008; Branski et al., 2008; Gajiwala and Gajiwala, 2004; Gajiwala and Lobo Gajiwala, 2003; Kesting et al.,
2008; Ravishanker et al., 2003; Singh et al., 2004; Singh et al., 2008; Singh et al., 2007; Toda et al., 2007; Wilshaw et al., 2008).

The application of amnion in ocular surgery started about 70 years ago when non-separated fresh amnion and chorion membranes were used as a conjunctival graft (de Rotth, 1940). A few years later, the use of dried amniotic membrane to treat ocular burns was reported (Sorsby et al., 1947; Sorsby and Symons, 1946) followed by a case report describing grafting of amnion after surgery (Dansey-Browning, 1949). Only decades later, Tseng and his colleagues further refined the techniques to use preserved amniotic membrane in ophthalmic surgery and this became clinical practice (Kim and Tseng, 1995; Tseng et al., 1998; Tseng et al., 1997). Currently, ophthalmologists use amnion as a graft (grafted with the epithelium up) or a patch (in this case with the epithelium down) to cover and heal corneal, conjunctival, and limbal defects and surgery wounds (Burman et al., 2004; Dua et al., 2004; Gomes et al., 2005; Kruse and Cursiefen, 2008; Meller et al., 2000; Nubile et al., 2008; Rodriguez-Ares et al., 2004; Sangwan et al., 2007; Sippel et al., 2001; Sudha et al., 2008; Tosi et al., 2005). Additional studies in animal models are also being performed (Kim et al., 2009; Ono et al., 2007).

Finally, amnion has been used also as an allograft in general surgery for reconstructions (Fotopoulou et al., 2009; Madhira et al., 2008; reviewed in Dua etal., 2004), as an autograft in neonatal reconstruction surgery (Hasegawa et al., 2004), and as a scaffold in tissue engineering research (Niknejad et al., 2008).

\section{Amnion-derived stem cells}

The recent isolation of cells with stem cell features from human amnion and amniotic fluid, opens many new venues (reviewed in Evangelista et al., 2008; Fauza, 2004; Ilancheran et al., 2009; Marcus and Woodbury, 2008; Miki and Strom, 2006; Pappa and Anagnou, 2009; Parolini et al., 2008; Parolini et al., 2009; Prusa and Hengstschlager, 2002; Siegel et al., 2008; Toda et al., 2007; Insausti et al., 2010). The low immunogenicity and the immunomodulatory properties (Akle et al., 1981; Banas et al., 2008; Ilancheran et al., 2007; Kubo et al., 2001; Wolbank et al., 2009) make amniotic membrane-derived epithelial stem cells promising for regeneration of tissues and ultimately even organs. Moreover, they can express or can be induced to express organspecific proteins when transplanted into the target organ/tissue due to their multi-differentiation potential (Kakishita et al., 2000; Kakishita et al., 2003; Liu et al., 2009; Okawa et al., 2001; Perin et al., 2007; Sankar and Muthusamy, 2003; Takashima et al., 2004; Wei et al., 2003; Wu et al., 2006; Zhao et al., 2005). These cells can also function as transgene carriers in cell-mediated gene therapy. Promising results in this area have been obtained by in vivo studies using animal models (Kosuga et al., 2001; Liu et al., 2009; Meng et al., 2008; Nakama et al., 2006; Takahashi et al., 2001). Initial experiments show that cells derived from human amniotic fluid can be transduced by viral vectors as well, or used in cell transplantation studies (Grisafi et al., 2008; Pan et al., 2009).

Amnion membranes and amnion cells are easily available. At the time of birth, the fetal membranes remain without function and are normally discarded, making them readily available in large amounts. Isolation of cells from amnion is relatively easy and lowcost. This is in contrast to the small numbers of human adult and embryonic stem cells that can be isolated, and their labour- 
consuming isolation procedure. Not to mention ethical and religious issues related to the use of human embryonic stem cells. In the prenatal period, amniotic fluid becomes available by means of amniocentesis. During the interval to deliver, these cells could be expanded in order to be used after birth, in case the index fetus would require them, e.g. when reconstructing a congenital birth defect (autologous grafting) (Kaviani et al., 2001).

\section{Properties of the amniotic membrane}

The human amniotic membrane at term has a number of properties that made its clinical use a success. This includes the absence of inducing an immune reaction, and having rather an anti-inflammatory effect. The amnion has been described as antiangiogenetic and bacteriostatic, and having even analgesic properties. It promotes re-epithelization and prevents scarring, and functions as an evaporation barrier (Dua et al., 2004; Ganatra, 2003; Gomes et al., 2005; Hao et al., 2000).

The human amnion indeed possesses low or no immunogenicity. In 1981, fresh amniotic membrane was transplanted subcutaneously in the arm of seven volunteers, and none of them showed acute immune rejection (Akle et al., 1981). Kubo and colleagues (Kubo et al., 2001) tested the immunogenicity of cryopreserved human amniotic membrane in rats. After transplantation in immunologically unprivileged sites (such as limbal area and under the kidney capsule), only a mild immune response was observed. When transplanted inside the cornea (an immune-privileged site) the grafts did not induce any immune reaction whereas control skin grafts were rejected.

Human amniotic epithelial and mesenchymal cells showed a contact- and dose-dependent immunosuppressive effect (Wolbank et al., 2007). Bailo et al. evaluated the engraftment potential of human amniotic and chorionic cells and showed that these cells do not cause an allogenic or xenogenic immune response, and actively suppress lymphocyte proliferation (Bailo et al., 2004). The inhibition of lymphocyte proliferation by human amniotic cells has been confirmed by other studies (Banas et al., 2008, Li et al., 2005, Wolbank et al., 2007). Furthermore, when introduced in neonatal swine and rats, these cells actively migrated and colonized specific organs, as demonstrated by human microchimerism. However, recipients of fresh amniotic membrane allografts transplanted into cornea did display antigenicity and immunogenicity (Hori et al., 2006).

Several mechanisms have been proposed to explain the immune-privileged status of the amnion. First of all, cells from the fetal membranes having immunomodulatory properties may be involved in the maintenance of fetomaternal tolerance (reviewed in Parolini et al., 2008). It has been shown that the human leukocyte antigens (HLA) class I are expressed in amniotic epithelial and mesenchymal cells whereas HLA class II antigens are not synthesized in cells of the amniotic membrane (Banas et al., 2008; Ilancheran etal., 2007; Kubo etal., 2001). Epithelial and mesenchymal amniotic cells secret a number of anti-inflammatory proteins like Activin A, IL-1 receptor antagonist (IL-1ra), and $\mathrm{IL}-10$ which are deposited within the amniotic membrane stroma (Hao et al., 2000; Hori et al., 2006; Kanyshkova et al., 2001; Keelan et al., 2000; Li et al., 2005). Hyaluronic acid may act as a ligand for CD44 and may entrap inflammatory cells in the stroma (Higa et al., 2005). Suppression of proteinase and MMP activation by amniotic membrane leads to decreased infiltration of inflammatory cells (Kim et al., 2000). Moreover, pro-apoptotic activity of the amniotic membrane was also reported - amnion can promote the apoptosis of leucocytes (Li et al., 2006; Zhou et al., 2003). Amniotic epithelial cells express the apoptosis-inducing genes Fas L, TNF, and TRAIL (Li et al., 2005).

Human amniotic membrane has been shown equally effective as autologous skin grafts, but superior to allo- and xenogenic skin grafts for decreasing bacterial counts in open granulating rat wounds (Robson and Krizek, 1973; Robson et al., 1973). Kanyshkova et al. (2001) reported the presence of the antibacterial protein lactoferrin in the membrane.

Amniotic membrane is one of the very few human tissues that are completely avascular, hence its ascribed anti-angiogenic properties. Anti-angiogenic factors (endostatin, TSP-1 and TIMPs) are produced within the amnion, but also angiogenic factors like VEGF and bFGF have been shown to be present in amniotic membrane (Bogic et al., 2000; Hao et al., 2000; Mignatti et al., 1989). Depending on the setting of in vitroand in vivoexperiments with amnion or amnion-derived cells, either suppression (Grueterich et al., 2003; Hori et al., 2006) or promotion of neovascularisation (Mahgoub et al., 2004) has been reported.

\section{Stem cell characteristics of amnion-derived cells}

Current understanding of pluripotency is based on extensive studies of mouse and human embryonic stem cells (ESCs), and more recently also of induced pluripotent stem (iPS) cells (Takahashi and Yamanaka, 2006). To be defined as pluripotent, these cells should fulfil specific criteria. In general, they have to be capable of unlimited self-renewal and of differentiation into the three embryonic germ layers (ectoderm, mesoderm, and endoderm). A full list of the current general criteria to evaluate the developmental differentiation potential of cells was provided by Jaenisch and Young (2008), namely: in vitrotri-lineage differentiation (e.g. embryoid bodies), in vivo formation of teratoma, formation of postnatal chimera, germline contribution, and tetraploid complementation. The golden standard to test pluripotency in mice is injection of cells into a blastocyst, or aggregation of cells with a morula, and contribution of the daughter cells to all germ layers in the embryo. Contribution to the germ lineage is the ultimate proof of pluripotency. However, this method is hardly applicable in human, where the standard pluripotency tests for candidate stem cells are tri-lineage differentiation in vitro, and formation of teratomas containing cells of the three germ layers in mice.

In 2004, Tamagawa and colleagues reported the isolation of a pluripotent stem cell line derived from cultured whole human amniotic membrane. These stem cells contributed to the formation of chimeric mouse/human embryoid bodies in vitro, giving rise to cells with characteristics of the primordial liver, lung, and digestive tract, but also to neural, epithelial and haematopoietic cells, and blood vessels. Hence, in this in vitroexperiment human amnion-derived cells seem to give rise to cells of all three germ layers (Tamagawa et al., 2004).

A number of studies followed, reporting that preparations of amniotic epithelial cells (AECs) and amniotic mesenchymal cells (AMCs), but also of cells collected from amniotic fluid (AFCs), all seem to contain cells with certain stem cell properties. These cells 
possess a high proliferation potential, express markers (such as OCT4) specific to pluripotent stem cells, and display the potential to differentiate in vitro into cells of all three germ layers (Alviano et al., 2007; De Coppi et al., 2007; Ilancheran et al., 2007; Kim et al., 2007; Miki et al., 2005; Tamagawa et al., 2007; Zheng et al., 2008).

OCT4 is one of the crucial stem cell markers (Brivanlou et al., 2003). It is a POU-domain type transcription factor that plays a critical role in maintaining pluripotency and self-renewal. OCT4 is synthesized in human and mouse ES cells, in embryonic carcinoma cells and in various pluripotent stem cell cultures. In early mouse embryos Oct4mRNA is expressed in pluripotent cell types such as cleavage stage blastomeres, the inner cell mass, and the epiblast. It is commonly accepted that Oct4 expression becomes progressively downregulated in somatic cells after gastrulation, but remains maintained in the primordial germ cells, and subsequently in the embryonic germ cells. This expression pattern reflects the direct regulatory function of Oct4 in maintaining pluripotency. The expression of OCT4 mRNA and protein in human amnion-derived cells suggests that the latter could still have similar properties as the epiblast stem cells from which they derive (reviewed in Miki and Strom, 2006). However, recent data from the mouse protein revealed Oct-3/4 presence in a continuum of morphologically distinct epiblast-derived embryonic and extraembryonic tissues up to embryonic day (E)8.5 which suggests potentially far more versatile roles of Oct4 in development than previously appreciated, including roles in differentiation (Downs, 2008; M.D., unpublished).

Importantly, amnion-derived cells do not express haematopoietic or monocytic marker genes, excluding the possibility that the observed plasticity of these cells is due to contamination with stem cells from cord or fetal blood, or with embryonic fibroblasts (In 't Anker et al., 2003; Miki et al., 2005; Tsai et al., 2007).

Recently, Parolini et al. published a survey on the isolation procedures of the different amnion-derived stem cell types, their detailed phenotypes and differentiation capacities, together with the differentiation protocols that have been used (Parolini et al., 2008; Mike et al., 2010). Amnion-derived cells are normally cultured in standard DMEM-based medium supplemented with $10 \%$ (amniotic membrane-derived cells) or $20 \%$ (AFCs) fetal serum, with or without EGF or bFGF, and mostly in the absence of LIF (Alviano et al., 2007; Kobayashi et al., 2008b; Miki et al., 2005; Sakuragawa et al., 2004; Zheng et al., 2008; Mike et al., 2010). Here, we highlight their stem cell features, compared to human ESCs (Table 1).

\section{Amniotic epithelial cells}

When freshly isolated from human term amnion, AECs have been shown to express the stem cell surface marker proteins SSEA-3, SSEA-4, TRA 1-60, TRA 1-81, Thy-1, and c-kit (receptor for the stem cell factor, SCF), but not the hematopoietic stem cell marker CD34, which excludes contamination with hematopoietic stem cells from the umbilical cord blood or the embryo (Miki et al., 2005). Stage-specific antigens (SSEA) 3 and 4, and tumor rejection antigens (TRA) 1-60 and 1-81, are well recognised cell surface markers for human ES cells, initially raised as a set of antibodies against human embryonic carcinoma cells (Andrews et al., 1984; Kannagi et al., 1983). Freshly isolated AECs share many other cell-surface antigens with human ES cells as well. However, these proteins are not homogenously expressed by all AECs, with some of them being very rare, and others - quite ubiquitous, suggesting that naïve AECs are a heterogenous cell population (Miki and Strom, 2006).

Along with the surface markers, both freshly isolated and cultured AECs express molecular markers typical for pluripotent human ES cells, i.e. OCT4, SOX2, LEFTY2 ( $\angle E F T Y-A)$, FGF4, REX1, CRIPTO and NANOG (Miki et al., 2005; Miki and Strom, 2006; Simat etal., 2008). OCT4, SOX2 and NANOG are transcription factors known to be required for self-renewal and/or pluripotency (Boiani and Scholer, 2005; Chambers et al., 2003; Nichols et al., 1998). Presence of mRNA for OCT4, SOX2, CRIPTO, NANOG, DPPA3 (STELLA), PROM1 (CD133) and PAXG was reported also in term human amnion, as well as in freshly isolated

TABLE 1

\section{STEM CELL PROPERTIES OF HUMAN AMNIOTIC MEMBRANE AND AMNIOTIC FLUID DERIVED CELLS COMPARED TO HUMAN EMBRYONIC STEM CELLS}

\begin{tabular}{|c|c|c|c|c|c|}
\hline \multirow[b]{2}{*}{ Cell type } & \multicolumn{2}{|r|}{ Expression of stem cells markers } & \multicolumn{2}{|c|}{ Differentiation capacity } & \multirow[b]{2}{*}{ Self-renewal capacity } \\
\hline & $\begin{array}{l}\text { Transcription } \\
\text { factors }\end{array}$ & Cell surface markers, secreted factors & In vitro & In vivo & \\
\hline ES cells & $\begin{array}{l}\text { NANOG, OCT4, } \\
\text { REX1, SOX2 }\end{array}$ & $\begin{array}{l}\text { ABCG2, AP, CD9, CD24, CD30, CD90/Thy-1, cKit, Cripto, } \\
\text { DPPA5, E-cad, FGF4, Integrin a6, Integrin } \beta 1 \text {, Lefty-2, } \\
\text { SCF, SSEA-3, SSEA-4, TRA 1-60, TRA 1-81, Vimentin }\end{array}$ & $\begin{array}{l}\text { Ectodermal, mesodermal and } \\
\text { endodermal differentiation }\end{array}$ & Teratoma formation & $\begin{array}{l}\text { Telomerase activity: YES } \\
\text { Tumorigenicity: YES } \\
\text { Clonogenicity: YES }\end{array}$ \\
\hline AECs & $\begin{array}{l}\text { NANOG, OCT4, } \\
\text { REX1, SOX2 }\end{array}$ & $\begin{array}{l}\text { ABCG2, CD9, CD24, CD44, CD73/SH3/4, CD90/Thy-1, } \\
\text { CD105/SH2, CD166, (cKit), cMet, Cripto, DPPA3, E-cad, } \\
\text { FGF4, Integrin a5, Integrin a6, Integrin } \beta 1 \text {, Lefty-2, PAX6, } \\
\text { PROM1, SCF, SSEA-3, SSEA-4, TRA 1-60, TRA 1-81 }\end{array}$ & $\begin{array}{l}\text { Ectodermal, mesodermal and } \\
\text { endodermal differentiation }\end{array}$ & $\begin{array}{l}\text { Ectodermal, mesodermal and } \\
\text { endodermal differentiation/ } \\
\text { functionality after transplantation } \\
\text { in animal models }\end{array}$ & $\begin{array}{l}\text { Telomerase activity: NO } \\
\text { Tumorigenicity: NO } \\
\text { Clonogenicity: YES/NO } \\
\text { (llancheran et al. 2007, } \\
\text { Bilic et al. 2008) }\end{array}$ \\
\hline AMCs & $\begin{array}{l}\text { NANOG, OCT4, } \\
\text { REX1, SOX2 }\end{array}$ & $\begin{array}{l}\text { CD13, CD29, CD44, CD46, CD54, CD59, CD73/SH3/4, } \\
\text { CD90/Thy-1, CD105/SH2, CD140a, CD166, CK19, (cKit), } \\
\text { Integrin a2, Integrin a3, Integrin a4 } \\
\text { SCF, Integrin } \frac{\text { SSEA-3, SSEAtin, }}{\alpha 5-4, \text { Vimentin }}\end{array}$ & $\begin{array}{l}\text { Ectodermal, mesodermal and } \\
\text { endodermal differentiation }\end{array}$ & $\begin{array}{l}\text { Mesodermal differentiation/ } \\
\text { functionality after transplantation } \\
\text { in animal models }\end{array}$ & $\begin{array}{l}\text { Telomerase activity: NO } \\
\text { Tumorigenicity: ND } \\
\text { Clonogenicity: NO }\end{array}$ \\
\hline AFCs & $\begin{array}{l}\text { GATA4, } \\
\text { NANOG, OCT4, } \\
\text { REX1 }\end{array}$ & $\begin{array}{l}\text { AP, cKit, CD29, CD44, CD54, CD73/SH3/4, CD90/Thy-1, } \\
\text { CD105/SH2, CD166, CK18, cKit, FGF5, Integrin a5, } \\
\text { (Nestin), SCF, SSEA-4, TRA 1-60, Vimentin }\end{array}$ & $\begin{array}{l}\text { Ectodermal, mesodermal and } \\
\text { endodermal differentiation }\end{array}$ & $\begin{array}{l}\text { Mesodermal differentiation/ } \\
\text { functionality after transplantation } \\
\text { in animal models }\end{array}$ & $\begin{array}{l}\text { Telomerase activity: YES } \\
\text { Tumorigenicity: NO } \\
\text { Clonogenicity: YES }\end{array}$ \\
\hline
\end{tabular}

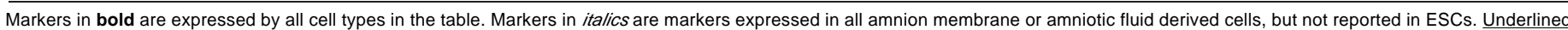

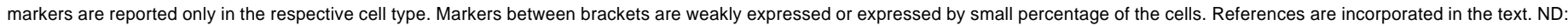
not determined. 
AECs (Ilancheran et al., 2007). Miki and colleagues cultured AECs in presence of EGF and obtained spheroid bodies. Expression of OCT4 and NANOGmRNA increased during the spheroid formation, and the presence of SSEA-3, SSEA-4, TRA 1-60, TRA 1-80 and OCT4 proteins in the spheroids was confirmed by immunofluorescence. After five days in culture, the authors reported higher expression of OCT4, NANOG, and the surface markers in the middle fraction of cells, rather than in the adherent fraction (Miki et al., 2005).

In 2002, adult mesenchymal stem cells were derived from the bone marrow, the MAPCs (multipotent adult progenitor cells). These cells express OCT4 and have pluripotent differentiation ability in vitro and in vivo. The OCT4 mRNA expression levels in MAPCs are up to 1000 times lower than in ES cells (Jiang et al., 2002). In contrast, monkey AECs seem to have similar OCT4 expression to that of ES cells, which may put AECs closer to ES cells than to adult stem cells (Miki and Strom, 2006).

Human AECs are shown to have trilineage differentiation ability in vitro, yielding cells of the pancreatic and hepatic endoderm, neuro-ectoderm and cardiac mesoderm lineages (Miki et al., 2005). The differentiation ability of established amniotic epithelial cell lines towards either neuronal/glial or hepatic cell types was already described earlier (Sakuragawa etal., 1996; Takashima et al., 2004). A more extensive study documented the differentiation of human AECs into neurons and astrocytes, hepatic and pancreatic cells, but also cardiomyocytes and other myocytes, osteocytes and adipocytes (Ilancheran et al., 2007; Niknejad et al., 2010). After culturing in the corresponding conditions, AECs expressed markers and produced proteins specific for the respective differentiated cell types, or for their progenitors, and acquired their specific morphology.

These in vitro results have been supported by several in vivo studies in animal models. Transplanted in the brain AECs were able to secrete dopamine (Kakishita et al., 2000; Kakishita et al., 2003) and to display neuroprotective function in rat and mouse models of Parkinson's disease (Kakishita et al., 2000; Kakishita et al., 2003; Kong et al., 2008). After transplantation in monkeys with spinal cord injury, AECs seemed to have repairing effects equal to that of transplanted neural tissue (Sankar and Muthusamy, 2003). AECs, transplanted into diabetic mice, produced insulin and normalized blood glucose levels (Wei et al., 2003). Despite their in vivo contribution, germline transmission has never been demonstrated.

AECs are also used in cell-mediated gene therapy experiments, combining the beneficial effects of AECs themselves with the introduction of therapeutic gene (Nakama et al., 2006). Cultured AECs were shown to secrete albumin; after transfection with LacZ gene and transplantation into SCID mice, these cells were found to integrate into the liver (Sakuragawa et al., 2000). A recent study (Liu et al., 2009) shows that both overexpressing GDNF and non-transfected AECs survive, migrate to the ischemic area, express neuronal markers and ameliorate the behavioural dysfunction in rat middle cerebral artery occlusion model. Meng et al. (2008) reported functional recovery in spinal-cord injured rats after co-transplantation of AECs, overexpressing bFGF, and neural stem cells.

Telomerase is limited to immortal cells, such as malignant cells, but also ESCs and germ cells. Unlike ESCs, freshly isolated AECs do not synthesize telomerase (Ilancheran et al., 2007; Miki etal., 2005). Furthermore, it has been reported that the latter cells are not tumorigenic. They do not form teratomas in vivo upon transplantation into severe combined immunodeficiency (SCID) or immunodeficient Rag2 $2^{-/}$mice, unlike ES cells (Ilancheran et al., 2007; Miki et al., 2005). On one hand, this finding gives strong advantage to AECs compared to ES cells regarding their potential use in regenerative medicine. On the other hand, it could also mean that AECs lack the ability to differentiate in vivo. In contrast to human amnion-derived stem cells, cultured ratamnion-derived cells isolated from E13.5 to E21.5 do contain telomerase, with telomerase activity higher at midgestation (E13.5 to E15.5) than during late stages and term (E17.5 to E21.5) (Nakajima et al., 2001). Data is still lacking on mouse AECs.

Evidence for long-term self-renewal is still not available for human AECs, which may be due to the absence of telomerase that limits their ability to divide in culture, and, subsequently, their self-renewal. Human AECs have been claimed to be clonogenic by Ilancheran and co-workers (2007), which was however not confirmed by the study of Bilic et al. (Bilic et al., 2008).

Recent work with whole-mount immunofluorescence analysis of freshly isolatedterm human amniotic membrane revealed that only cells in amniotic epithelium and not in amniotic mesenchyme reacted with antibodies raised against the pluripotency markers SSEA-3, SSEA-4, TRA 1-60 and TRA 1-80 (Miki et al., 2007). This suggests the in vivo presence of (pluripotent) amniotic epithelial stem cells, rather than being induced in cell culture, although the data on protein presence of OCT4 or NANOG is still lacking. Even though these data question the in vivo presence of stem cells in amniotic mesenchymal cells, they raise the possibility that these cells may keep plasticity and can acquire stem cell features in vitro. Miki et al. showed that these stem cell-like cells are distributed in a scattered fashion within the amniotic epithelium. The TRA-positive cells represent intriguingly $10-20 \%$ of the epithelial cells, which is a very high frequency compared to adult tissuespecific stem cells (0.1-0.01\%). However, there is heterogeneous reactivity to the different stem cell marker antibodies used. The authors explain this observation as amniotic epithelial cells being in different stages of differentiation (Miki et al., 2007).

\section{Amniotic mesenchymal cells}

Mesenchymal Stem Cells (MSCs) isolated from human adult bone marrow (Fridenshtein, 1982) show high in vitro expansion potential and self-renewal capacity and have the ability to differentiate into multiple mesoderm-type cells in vitro (Oswald et al., 2004). Human amniotic membrane may also be an abundant source of MSCs. According to the nomenclature of the International Society for Cellular Therapy, the mesenchymal cells derived from amnion are now named Amniotic Membrane-human Mesenchymal Stromal Cells (AM-hMSCs) (Horwitz et al., 2005). AM-hMSCs isolated after in vitro culture of term amnion show immunophenotypical profile consistent with that described for bone marrow-human mesenchymal stromal cells (BM-hMSCs). They are positive for the Src homology domains $(\mathrm{SH})$ of the Src family of proto-oncogenic tyrosine kinases - $\mathrm{SH} 2, \mathrm{SH} 3$, and $\mathrm{SH} 4$ (Alviano et al., 2007), as well as for the clusters of differentiation (CD) 13, CD29, CD44, CD166, and negative for the hematopoietic markers CD14, CD34, and CD45 (Alviano et al., 2007; Kobayashi et al., 2008b; Soncini et al., 2007). In addition they express OCT4 mRNA in higher levels than BM-hMSCs (Alviano 
et al., 2007). Side population cells isolated by FACS from human AM-hMSCs were positive for OCT4, SOX2, REX1 and NESTIN (neural stem cell marker) mRNA, and for OCT4 protein (Kobayashi et al., 2008b). The expression of OCT4, SOX2, REX1, NANOG, and $S C F$ (stem cell factor, ligand of c-kit) as well as the presence of OCT4, NANOG, SSEA-3, and SSEA-4 proteins, but not TRA 161, was further documented for cultured AMCs (Kim et al., 2007; Tamagawa et al., 2007). Recently, human iPS cells have been estsablished from amniotic membrane cells (Cai et al., 2010).

AMCs differentiate in culture towards different mesodermal cell types, like i.e. adipogenic, chondrogenic, osteogenic, skeletal- and cardio-myogenic, and endothelial cells (Alviano et al., 2007; Kim et al., 2007; Kobayashi et al., 2008b; Li et al., 2008; Soncini et al., 2007; Tamagawa et al., 2007; Wolbank et al., 2009; Zhao et al., 2005); but they also display potential to differentiate into hepatocyte-like cells (Tamagawa et al., 2007) and into neuroglial cells (Kobayashi et al., 2008b; Sakuragawa et al., 2004). Upon differentiation they express genes and produce proteins specific to the given cell type. AMCs, differentiated to myofibroblasts, are able to revert to a fibroblast phenotype after appropriate culturing (Li et al., 2008). AM-hMSCs may represent a valuable alternative source for mesenchymal stem cell-based therapies when compared to BM-hMSCs. Alviano and co-authors showed that AM-hMSCs may be considered as superior to adult MSCs in their proliferation and differentiation potential, likely due to their higher OCT4 mRNA levels (Alviano et al., 2007). In addition, the same authors reported remarkable angiogenic potential of AMCs.

In vivo, human AMCs are shown to survive after transplantation in rat hearts, and to undergo cardiac differentiation without immunological rejection (Zhao et al., 2005).

\section{Amniotic fluid derived cells}

Amniotic fluid contains diverse cell types from all three germ layers derived from the skin and the digestive tract of the developing embryo/fetus, and from the amniotic membrane (Gosden, 1983; Fauza, 2004). AFCs can be collected during the second trimester of gestation by amniocentesis. Amniotic fluid is rich in mesenchymal stem cells (Fauza, 2004; Siegel et al., 2008) that possess high proliferation potential, are OCT4 positive; and are able to differentiate into cells types of the three germ layers, like adipogenic, osteogenic, myogenic and endothelial cell types, neurogenic cell types, and hepatic cell types (De Coppi et al., 2007; You et al., 2008; Zheng et al., 2008). A recent study reported that C-Kit+ Lin- cells derived from human amniotic fluid displayed a multilineage differentiation potential in vitro to the haematopoietic lineages (Ditadi et al., 2009).

Although amniotic fluid derived cells have been long time used for genetic diagnostic purposes, only recently their properties and origin were documented. The first evidence of a distinct population of stem cells in human amniotic fluid was obtained by two research teams independently (Prusa and Hengstschlager, 2002; Prusa et al., 2003; In 't Anker et al., 2003). These cells expressed OCT4 mRNA (Prusa et al., 2003), scored positive for mesenchymal markers such as CD90, CD105 (SH2), CD73 (SH3/4), CD166 but were negative for hematopoietic markers such as CD45, CD34, CD14 (In 't Anker et al., 2003). Tsai and colleagues showed that AFCs expressing OCT4, CD44 and CD105, but not expressing CD34, have osteogenic, adipogenic, and neuronal differentia- tion potential (Tsai et al., 2004).

Further evidence came from De Coppi et al. in 2007. They isolated clonal cell lines from human OCT4 positive AFCs that confirming the first study - were positive for mesenchymal but negative for haematopoietic markers. In addition, the authors were able to demonstrate differentiation from such cloned AFCs into cell types representing adipogenic, osteogenic, myogenic, endothelial, neurogenic and hepatic cell types. In addition, these amniotic fluid stem (AFS) cells were not tumorigenic, retained long telomeres, and maintained a normal karyotype for over 250 population doublings (De Coppi et al., 2007). The presence of NANOG protein and SSEA-4 in human AFS cells (Roubelakis et al., 2007), their differentiation into chondrocytes (Kim et al., 2007; Kolambkar et al., 2007) and osteocytes (You et al., 2008), and the presence of telomerase activity (Kim et al., 2007) have been reported. It seems therefore that AFS cells are pluripotent stem cells similar to - but less differentiated - than BM-MSCs (Kim et al., 2007). Recently, Perin et al. showed that human amniotic fluid-derived cells transfected with green fluorescent protein and Lac-Z and subsequently microinjected into murine embryonic kidneys contributed to the development of primordial kidney structures and they demonstrated viability of these cells in organ culture during 10 days (Perin et al., 2007).

A common theme in many publications on human amniotic stem cells is the speculation that amniotic epithelium may have retained stem cell features from the pluripotent epiblast from which they are derived. Given that amniotic membrane cells become separated early in their development from the epiblast per se, hence from locations of subsequent organogenesis, they may have been escaping from differentiation signals (Ilancheran et al., 2007; Miki et al., 2005; Miki et al., 2007; Tamagawa et al., 2004). To explore further whether amniotic epithelium retains pluripotent stem cell features from the epiblast, it would be useful to consider functional studies in other species than primates. One way is to study amnion properties in (tissue specific) genetic mouse mutants that affect a component of a pathway that is crucial for stemness of the epiblast. Therefore, we consider it relevant to describe human amnion development, and to recapitulate how the amnion forms in rodents, in particular in mouse. We highlight the similarities but also the differences with human amnion development.

\section{Amnion development in humans}

The timing and mechanism of amnion formation varies among different amniotes. Comparative studies between human and rhesus monkey have shown that the process of amnion formation is basically equivalent in both species. Nevertheless, the amniotic cavity starts already to form as early as 7-8 days post fertilization (dpf) in the human embryo compared to $10 \mathrm{dpf}$ in rhesus monkey (Luckett, 1975).

The embryonic ectoderm (epiblast) gives rise to all fetal tissues, but also to amniotic ectoderm. In human, the amniotic ectoderm is the first structure that is readily distinguishable from the epiblast shortly after implantation, well before the onset of gastrulation (15-17 dpf) (Bianchi et al., 1993). The process of human amnion formation has remained fairly obscure. Historically, several researchers believed that amnion arose by cavitation of epiblast, while others favoured a folding process of the 
A

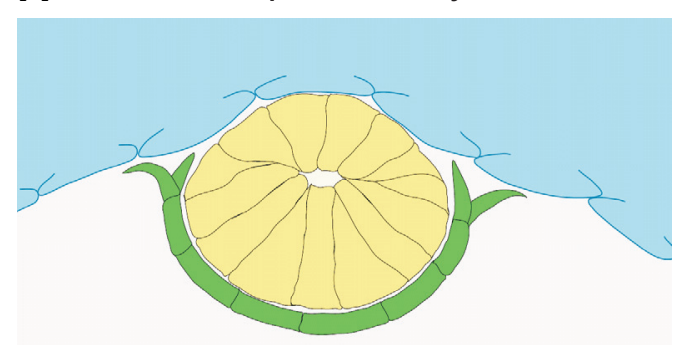

Embryonic ectoderm (epiblast)

Embryonic mesoderm

Amniotic ectoderm

Extraembryonic endoderm (hypoblast)

Extraembryonic mesoderm

Trophectoderm/Cytotrophoblast
B

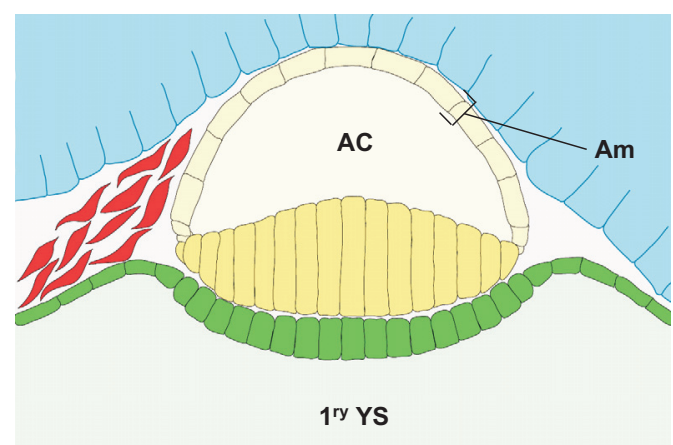

C

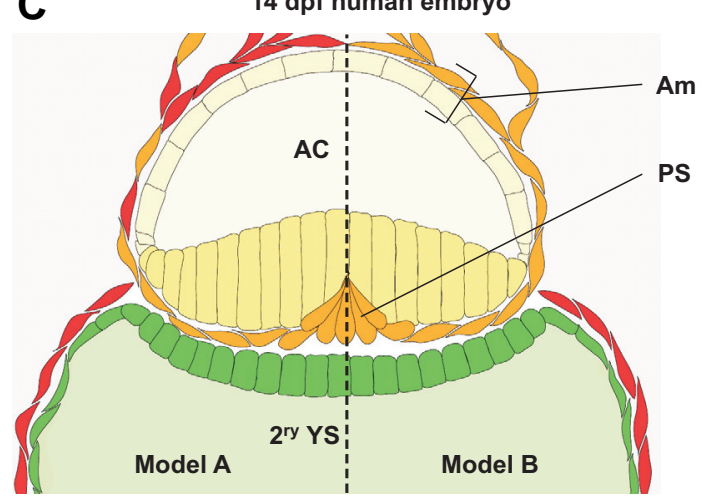

Fig. 2. Schematic representation of early stages of human amnion development. (A) Transverse section through a 7-8 dpf human embryo. (B) Transverse section through a 12 dpf human embryo. (C) Transverse section through the caudal region of the embryonic disc a 14 dpf human embryo. Two alternative models are represented. In model A, according to Enders and King, 1988 and Bianchi et al., 1993, amniotic mesoderm is derived of hypoblast and primitive streak. In model B, according to Robinson et al., 2002, amniotic mesoderm is primitive streak derived mesoderm. Abbreviations: AC, amniotic cavity; Am: amnion; PS: primitive streak; YS: yolk sac.

ectoderm; or suggested a combination of both (Luckett, 1975). A more extensive study in rhesus monkey has established cavitation as the process of amniogenesis (Enders et al. 1986). The authors reported that before implantation the epiblast consists of a loosely packed spherical cluster of cells. Soon after implantation (6 dpf), the epiblast cells start to polarize and re-arrange radially. Eventually, as the epiblast grows, a small cavity forms at the point where the radially organized epiblast cells converge. This cavity is called the proamniotic cavity, and the cells at its border contain microvilli. The epiblast cells that face the primitive endoderm (or hypoblast) have a more columnar shape than the cells facing the cytotrophoblast (Fig 2A). Shortly afterwards, when the cavity enlarges and the number of cells in the epiblast increases, the definitive amniotic cavity is formed. The ectodermal cells that face the cytotrophoblast constitute now the amniotic ectoderm (Fig. 2B). The remaining 'embryonic' ectoderm grows tangentially to the primitive endoderm (Enders et al., 1986). At this stage, the embryo starts to display its characteristic shape. Like most of the amniotes, humans have a disc-shaped embryo referred to as the embryonic disc. Morphologically, the epiblast cells in the embryonic disc are gradually less columnar from the centre towards the periphery. The recently formed amnion is continuous with the epiblast at the margins of the embryonic disc (Fig. 2B). The observations described here are coherent with cavitation as the

process of amniogenesis. However, the occasional appearance of erythrocytes within the amniotic cavity, and sections with disrupted amnion at those early stages led to a different interpretation. Lucket (1975) agreed that amniotic ectoderm is formed by cavitation, but suggested that this was followed by breakage of amniotic epithelium and reconstitution by folding. Enders et al.,1986) explains that the sporadic appearance of erythrocytes could be attributed to an occasional leakage of blood into the amniotic cavity during amnion formation. Moreover, disrupted amniotic epithelium can be the consequence of fractures during tissue processing. Therefore, amniotic ectoderm disruption and folding back into a continuous epithelium seems less likely.

At 8-10 dpf, the primate amnion is still a single layered membrane that lacks a mesodermal component. Indeed, amnion formation in primates can be regarded as a two-step process, where amniotic ectoderm formation precedes the appearance of the mesodermal component. Extraembryonic amniotic mesoderm was considered an epiblast-derived tissue in human and rhesus monkey (Hill, 1932; Luckett, 1978), which is in accordance to the situation in other eutherian species. Luckett's study (1978) reports the appearance of a thickening at the caudal margin of the embryonic disc around $12 \mathrm{dpf}$. According to the author, this would represent the primordium of the primitive streak. However, this is incompatible with the onset of gastrulation and intraembryonic mesoderm formation which occurs at 15-16 dpf (Bianchi et al., 1993) (Fig. $2 \mathrm{~B}$ ). Hence, the origin of the extraembryonic mesoderm in primates remains a matter of debate, because amniotic extraembryonic mesoderm is in contact with amniotic ectoderm already at 10 $12 \mathrm{dpf}$ (Bianchi et al., 1993).

Until now, data on the fate map of primate amniotic mesoderm is lacking. The existing studies have based their conclusions on morphological and cytological analysis of these tissues. Several authors hypothesize that amniotic mesoderm has an extraembryonic origin. Hertig and Rock (1949) suggested that extraembryonic mesoderm is derived from cytotrophoblast by delamination, whilst Heuser and Streeter (Heuser and Streeter, 1941) proposed that it is derived from the extraembryonic endoderm. A detailed cytological analysis in gastrulating rhesus monkey (Enders and King, 1988) and human embryos (Bianchi et al., 1993) identified a cell population located in proximity to the endoderm that gives 
rise to extraembryonic mesoderm. The authors propose that this cell population - which is likely the caudal thickening also observed by Lucket (1978) - is endoderm/hypoblast derived. Enders and King (1988) suggest that the streak contributes mainly to embryonic mesoderm but, due to massive increase of the latter, could also contribute later on to the extraembryonic mesoderm (Fig. 2C, model A). In contrast, a more recent study suggests that amniotic mesoderm has only an epiblast origin (Robinson et al., 2002), which is consistent with primitive streak-derived amniotic mesoderm (Hill, 1932; Luckett, 1978). Robinson and co-workers investigated the frequency of trisomic cells in amniotic epithelium and mesenchyme from human fetuses with placental mosaicism for trisomy. Based on their results, they conclude that both amniotic ectoderm and mesoderm are derived from epiblast. Consequently, amniotic mesoderm must be derived from primitive streak mesoderm rather than from hypoblast (Fig. 2C, model B). Alternatively, one might have to consider the possibility that the origin of extraembryonic mesoderm is not mutually exclusive for hypoblast or epiblast, but could rather be more complex and thus mosaic.

The formation of the amniotic membrane is just the very first step in amniogenesis. Soon after the extraembryonic mesoderm becomes closely associated with the amniotic ectoderm, the human amnion matures; this is characterized by accumulation of ECM proteins (Bryant-Greenwood, 1998). Besides conferring protection to the embryo, and containing the amniotic fluid, the amnion also regulates the composition and volume of amniotic fluid. For instance, in the early rhesus monkey embryo the amniotic epithelium is composed of squamous cells with few apical microvilli, and the epithelium is supported by a basal lamina. In the older embryo the amniotic epithelium cells are rather cuboidal, with numerous microvilli and an incomplete basal lamina (King, 1980). The resulting increased surface of the amniotic epithelium supports extensive exchange and transport across the membrane. By doing so, the amniotic membrane can regulate the volume and the composition of amniotic fluid, and can thus influence the fetal environment (reviewed in Schmidt, 1992). At about 17-20 weeks of gestation, the amnion expands outwards and fuses to the chorion (Ilancheran et al., 2009) (Fig. 1B).

\section{Amnion development in mouse}

Shortly after implantation (at E4.5) the conceptus is composed of epiblast (primitive ectoderm) surrounded by visceral endoderm in the lower half of the egg cylinder, and extraembryonic ectoderm enveloped by visceral endoderm in the upper half. The epiblast will give rise to the embryo proper, as well as the amniotic ectoderm and the extraembryonic mesoderm of chorion, amnion, visceral yolk sac and allantois, respectively (Gardner, 1978). At E5.0, a small cavity is formed by apoptosis in the centre of the epiblast, leading to the formation of a proamniotic cavity (Coucouvanis et al., 1995), and the embryo acquires its characteristic cup shape. The cavity enlarges with the growth of the egg cylinder and eventually faces also the extraembryonic ectoderm (Kaufman, 1992) (Fig. 3A).

Unlike the discoid primate embryo, the early post-implantation
Fig. 3. Schematic representation of early stages of mouse amnion development. (A) Prestreak mouse embryo at E6.5. (B) E7.0 mouse embryo at midstreak stage. The future anterior the posterior side is to the right. The most posterior mesoderm that is formed in the primitive streak migrates into the extraembryonic region, where it piles up. This creates the amniochorion-fold. The fold enlarges, and small lacunae will appear within the extraembryform a larger cavity, the exocoelom (not shown). (C) E7.5 mouse embryo at neural plate stage. Amnion and chorion fusion has occurred and thus divide the proamniotic cavity of the egg cylinder into the amniotic, exocoelomic and ectoplacental cavity. When chorion and ectoplacental cone meet, they side of the embryo is to the left, onic mesoderm which fuse to

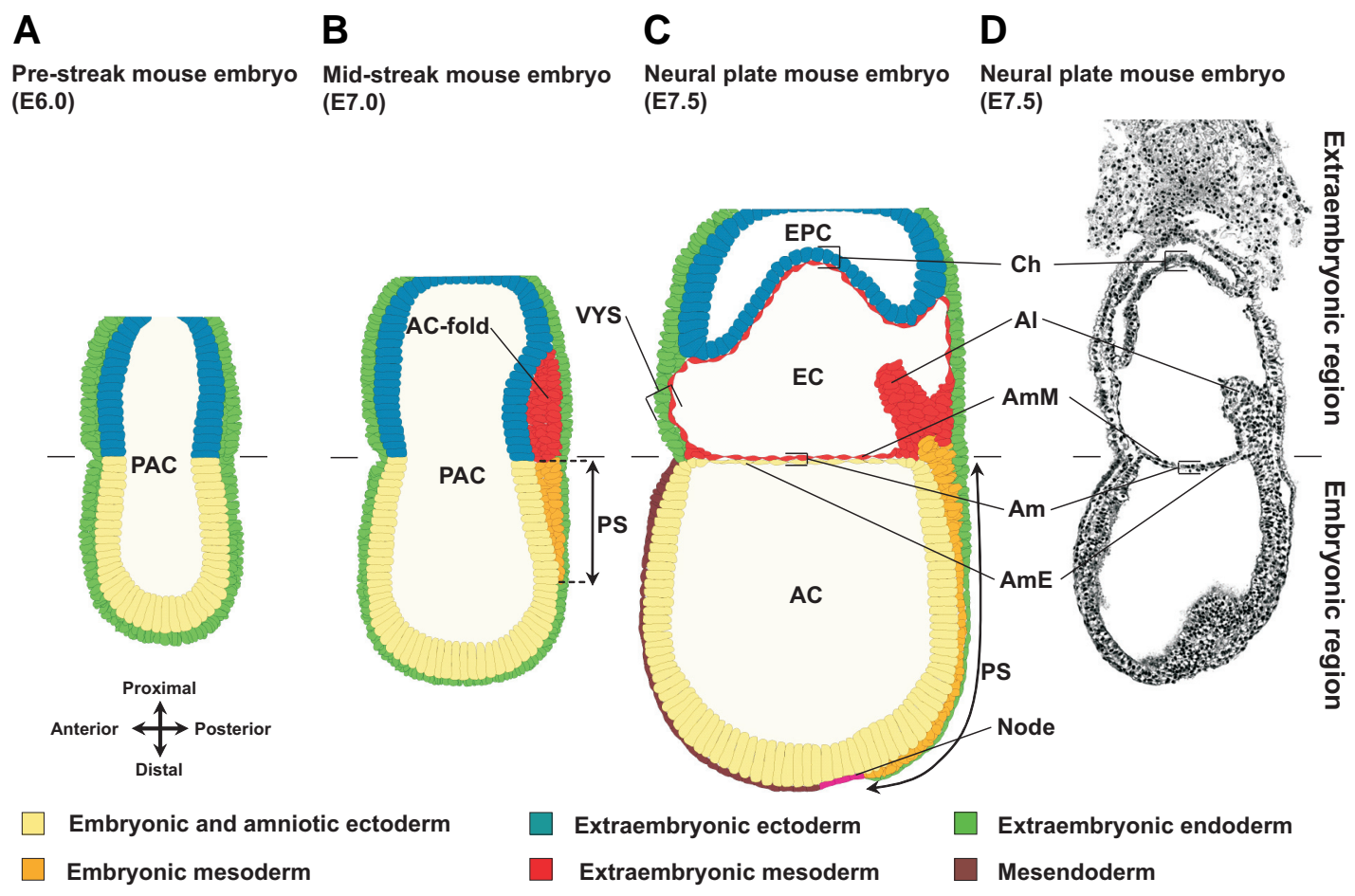
re-streak mouse embryo
Mid-streak mouse embryo Neural plate mouse embryo (E7.5)
Neural plate mouse embryo (E7.5)

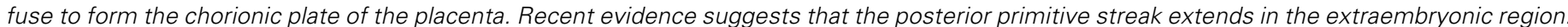
The extraembryonic compartment of the primitive streak creates a node-like cells reservoir from which the allantois emerges (Downs et al., 2009). (D) Sagittal section of an E7.5 mouse embryo. Abbreviations: AC, amniotic cavity; AC-fold: amniochorionic fold; Al: allantois; Am: amnion; AmE: amniotic ectoderm; AmM: amniotic mesoderm; Ch: chorion; EC: exocoelomic cavity; PAC: proamniotic cavity; EPC: ectoplacental cavity; PS: primitive streak; VYS: visceral yolk sac. 
rodent embryo has a cylinder shape (hence its name egg cylinder) and has inverted germ layers, with the ectoderm facing the inside of the cylinder, and the endoderm on the outer side (Fig. 3 A-C). In contrast to human amniotic development, formation of the amnion in mice initiates only at gastrulation. Gastrulation starts around E6.5 with the formation of the primitive streak at the posterior side of the epiblast at the level of the embryonicextraembryonic junction (Fig. 3B) (Beddington and Robertson, 1999; Tam and Beddington, 1992). At the mid-streak stage, a clear amniochorionic fold is formed at the posterior side of the embryo due to the accumulation of extraembryonic mesoderm between extraembryonic ectoderm and visceral endoderm, pushing the extraembryonic ectoderm and embryonic ectoderm into the proamniotic cavity. The extraembryonic mesoderm from the amniochorionic fold is the first and posterior-most mesoderm that leaves the streak and that migrates into the extraembryonic region (Kinder et al., 1999; Lawson et al., 1991; Tam and Beddington, 1987). This amniochorionic fold will give rise to both amnion and chorion, but also to the yolk sac mesoderm. Subsequently, small lacunae appear within the extraembryonic mesoderm; these fuse and form the exocoelomic cavity that enlarges from the posterior end, extends laterally around the egg cylinder, and then converges near to the anterior embryonic-extraembryonic junction area. Eventually, the extraembryonic and the embryonic ectoderm of the fold fuse with their counterparts at the anterior side of the egg cylinder. Mesoderm cells at the anterior end will protrude and intercalate between the amniotic and the chorionic ectodermal sheets, thus segregating both membranes (Fig. 3 C,D) (Gardner, 1978; Kaufman, 1992; Snell and Stevens, 1966; P.N.G.P., M.P.D., L. Graham, D. Huylebroeck, K.A. Lawson, A.Z, in preparation). During the growth of the egg cylinder the chorion is pushed proximally and amniotic and chorionic mem-

Fig. 4. Appearance of extraembryonic tissues and organs in mouse embryos and fetuses. (A-D) Schematic representation of the turning process in mouse between E8.5 and E9.5. As a consequence of the axial rotation, the embryo gets encased in its extraembryonic membranes. Adapted from Kaufman, 1992. (E) An E8.5 mouse conceptus (CD1 outbred strain) dissected free from the decidua and its parietal yolk sac. The visceral yolk sac masks the amnion, the chorion, the allantois and the embryo proper. Scale bar, 250 $\mu \mathrm{m}$. (F) Another E8.5 mouse embryo after removal of the visceral yolk sac. The amnion, the allantois and the embryo become better visible. The chorion - to which the allantois has fused at this stage - is hidden by the ectoplacental cone. Amnion and chorion are not in physical contact anymore at this stage. The embryo is still in its unturned lordotic position. Anterior is to the left, posterior to the right. (G) An E9.0 mouse embryo in the process of turning. The visceral yolk sac is removed. The amniotic membrane is avascular and transparent. (H) A turned E9.5 embryo. Scale bar (F-H) $500 \mu \mathrm{m}$. (I) Lateral view of an E11.5 fetus which is surrounded by its vascularised visceral yolk sac. A rim of parietal yolk sac covering the visceral yolk sac is still visible. For simplicity, the parietal yolk sac was not discussed in the text. It is a transient membrane derived of the mural trophectoderm and the parietal endoderm which is crucial for implantation and nutrition of the early embryo. The parietal yolk sac surrounds initially the whole conceptus. It is not the equivalent

A

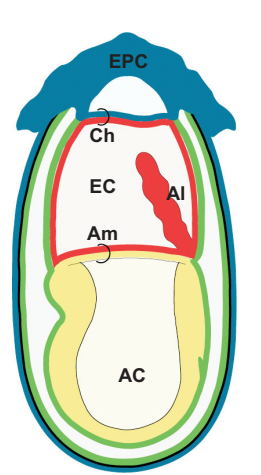

B
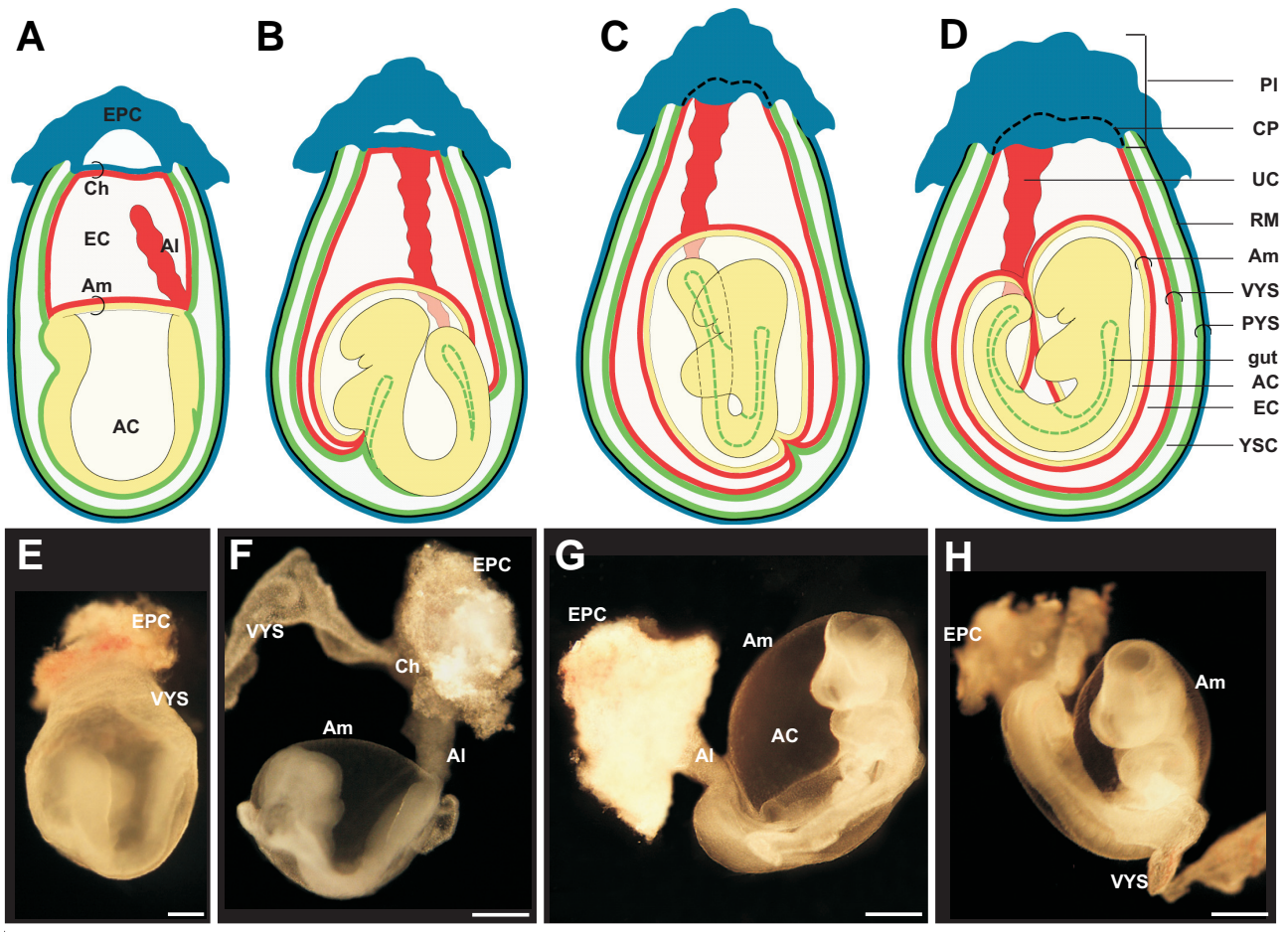

1
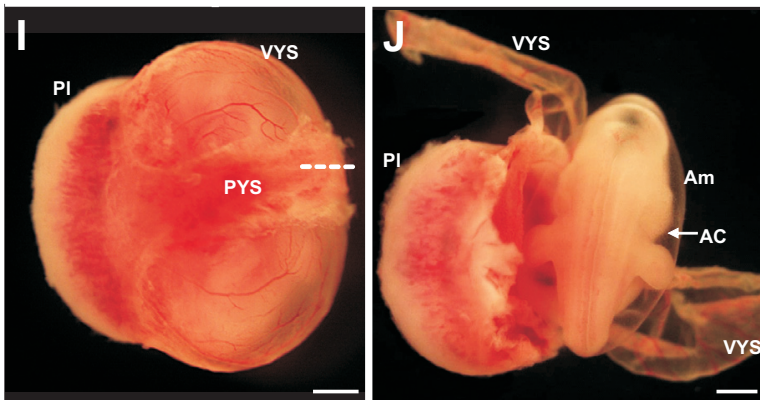

K

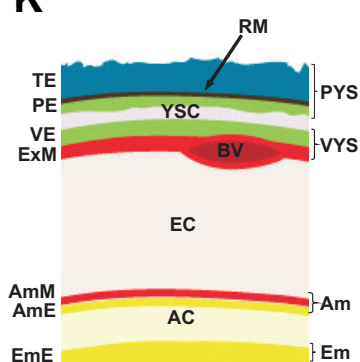

$\square$ EmE/AmE

$\square \quad$ ExM

$\square \quad \mathrm{ExE} / \mathrm{TE}$

$\square \quad$ VE of the human primary yolk sac. (J) Dorsal

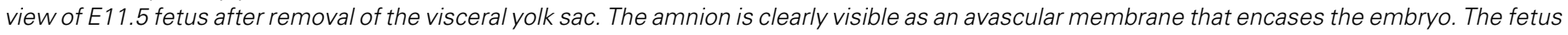

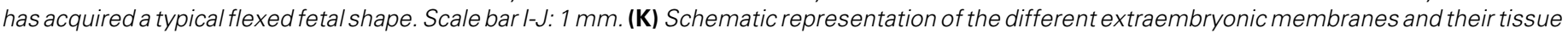

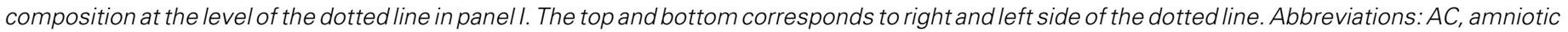

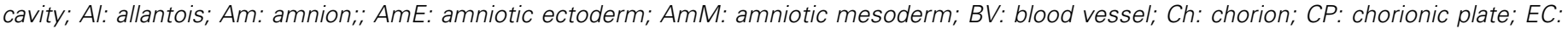

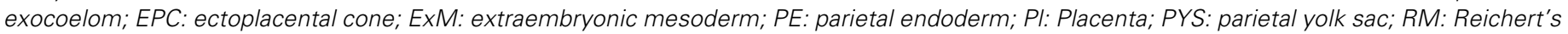
membrane; TE: trophectoderm; VE: visceral endoderm; VYS: visceral yolk sac; YSC: yolk sac cavity. 

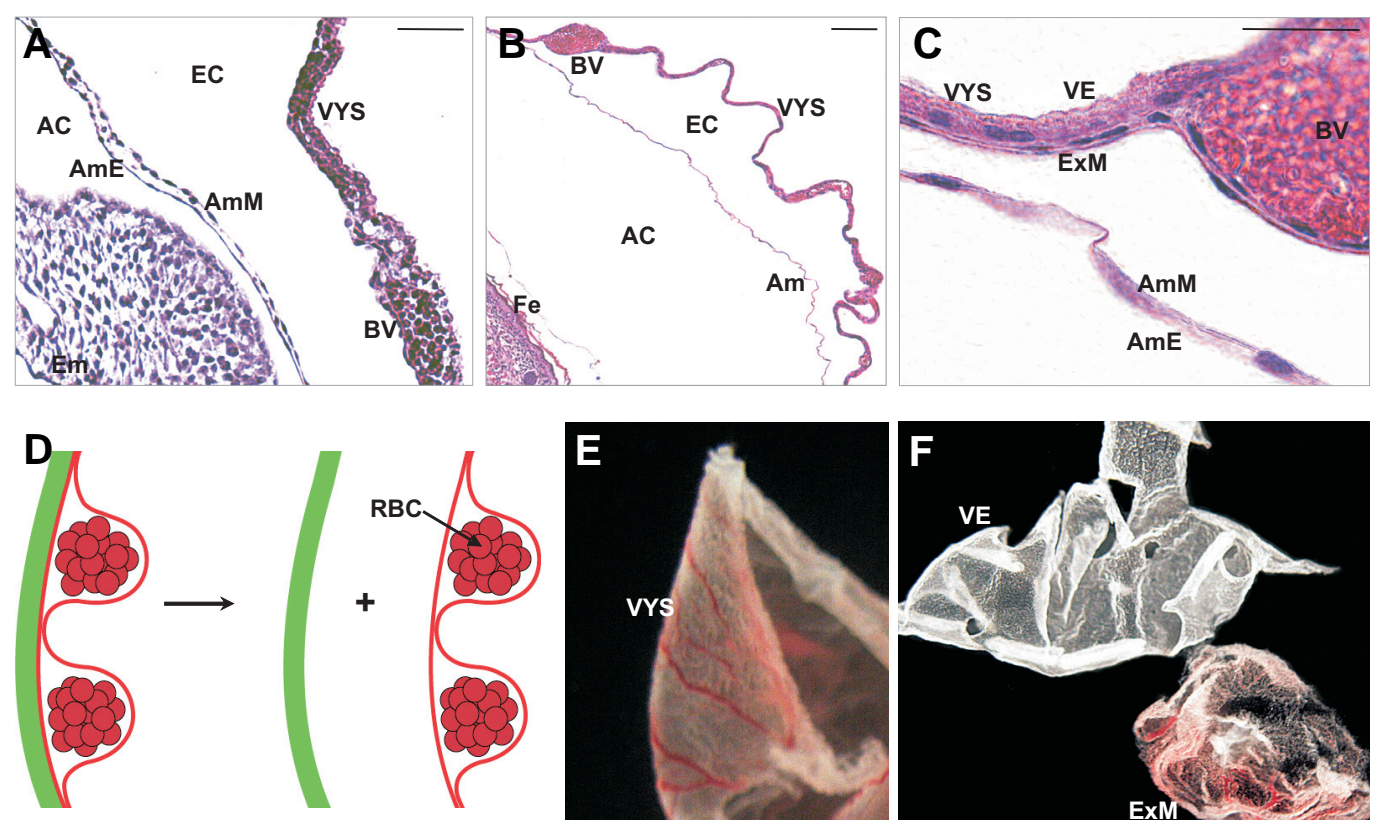

VYS
VE

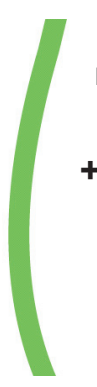

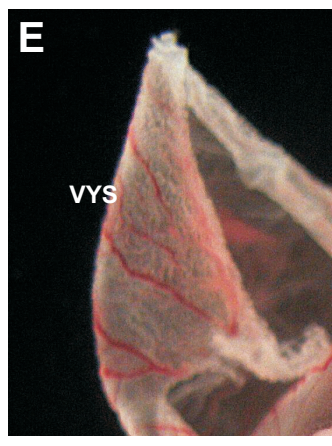

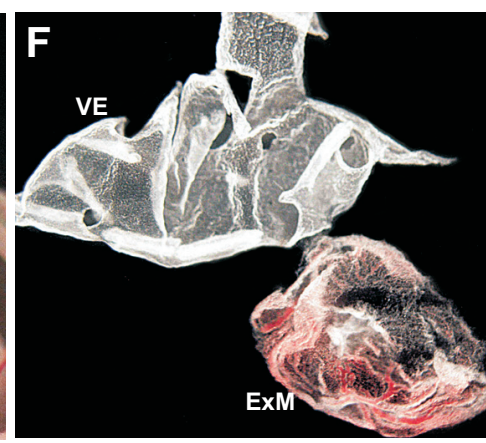

Fig. 5. Appearance of mouse amnion at midgestation and close to term. (A) Haematoxylin-eosin staining of a paraffin section through the amnion of an E9.5 mouse embryo (CD1 outbred strain). The amnion is flanked by the visceral yolk sac and the embryo proper. Scale bar: 50 $\mu \mathrm{m}$. (B) Haematoxylin-eosin staining of a paraffin section through the amnion of an E17.5 mouse fetus, which is approximately 2 days before birth. The amnion is flanked by the visceral yolk sac and the fetus. The avascular amnion is stretched extensively; and amniotic epithelium and mesoderm can not be distinguished easily. The vascularized visceral yolk sac is much thicker and can be expected to give more protection to the fetus than the amnion. Scale bar: $100 \mu \mathrm{m}$. (C) Magnification of the amnion represented in C. Scale bar: $25 \mu \mathrm{m}$. (D) Schematic representation of the visceral yolk sac at E9.5.

The murine visceral yok sac consists of extraembryonic endoderm and extraembryonic mesoderm. The latter is the layer in which blood islands are formed at E7.5 (Palis et al., 1995) (not represented in Fig. 4A-C). Blood islands coalesce subsequently to form a primitive vascular plexus and are remodeled further into a functional vascular network. (E) Microdissected intact visceral yolk sac. (F) The visceral yolk sac of an E9.5 mouse embryo after enzymatic separation and microdissection of the avascular visceral endoderm and the reddish extraembryonic mesoderm. Courtesy $L$. Cox. Abbreviations: AC: amniotic cavity; Am: amnion; AmE: amniotic ectoderm; AmM: amniotic mesoderm; BV: blood vessel; EC: exocoelomic cavity; RBC: red blood cells; VE: visceral endoderm; Em: embryo; ExM: extraembryonic mesoderm; Fe: fetus; VYS: visceral yolk sac.

branes divide the proamniotic cavity into amniotic, exocoelomic and ectoplacental cavity (Fig. 3 C,D). When chorion and ectoplacental cone meet, they fuse to form the fetal part of the placenta.

When the embryo displays 6-8 somites (around E8.5), it starts turning (Fig. $4 \mathrm{~A}-\mathrm{H}$ ) and becomes progressively transformed from a lordotic (Fig. $4 \mathrm{~A}, \mathrm{~B}, \mathrm{~F}$ ) position into the regular flexed fetal position (Fig. $4 \mathrm{D}, \mathrm{H}$ ) which is observed in most chordates. As a result of this turning process, which is completed at the 14-16 somite stage, the ectoderm acquires an exterior location and the embryo becomes entirely enwrapped by its amnion and visceral yolk sac (Kaufman, 1992). Due to the axial rotation, the amnion becomes positioned between the visceral yolk sac and the fetus (Figs. 4, 5). It is of note that from E7.5 onwards, amnion and chorion have become two completely separate membranes that are no longer in contact with each other (Fig. 3 C,D, 4 A,F), and hence the rodent amnion does not become incorporated in the placenta. The amnion remains through gestation a very thin and avascular membrane (Fig. 5). Like in primates, the amnion is reported to mature. The basal membrane contains fibronectin, laminin and collagen fibers (George et al., 1993; Scott et al., 1982),

\section{Differences in amnion development between mice and man}

At least six differences between primate and murine amnion development can be noted. Firstly, the early murine embryo is atypical in the sense that it is a cup-shaped embryo with inverted germ layers. Secondly, murine amnion formation is initiated relatively late during gestation, i.e. at the onset of gastrulation.
Thirdly, the driving force of amnion formation seems quite different in both species. In mouse, amnion formation happens by a folding process possibly triggered by the accumulation of extraembryonic mesoderm, and this happens early during gastrulation. Several independent gastrulation mouse mutants lack an amniochorionic fold because of the general deficit of extraembryonic mesoderm (reviewed in Tam and Loebel, 2007). Such mutants lack any sign of amniotic ectoderm formation. In primates, amnion formation is thought to initiate through cavitation (Enders et al., 1986). Fourthly, the origin of the murine amniotic mesoderm is less controversial; it is definitely the extraembryonic mesoderm, which is an epiblast derived tissue (Lawson et al., 1991; Smith et al., 1994). Fifthly, the murine amnion is a simple bilayered membrane that remains during the whole gestation surrounded by the visceral yolk sac (Figs. 4,5 ). It is plausible that the visceral yolk sac fulfils in rodents to a large extend the shock barrier function of the amnion in primates. Sixthly, the murine amnion does not make contact with the chorion and therefore does not become incorporated into the placenta.

\section{Amniotic stem cells: of mice and men}

Studies that investigate the origin of amniotic stem cells are eagerly awaited, as well as studies that aim to elucidate the molecular mechanisms that protect these stem cells from surrounding differentiation cues. The recent findings that up to 10 $20 \%$ of the human amniotic epithelium cells in intact term amnion express some stem cell markers, as assessed by whole mount immunohistochemistry of fresh amniotic membrane, are intriguing (Miki et al., 2007). Why are there at that time such a high 
number of cells with stem cell features present in a tissue that is predisposed to be shed at birth? Are these 'stem' cells continuously present in the amniotic epithelium in high numbers or are latent stem cells triggered to become full-blown stem cells at a given moment? How dynamic is this stem cell population throughout gestation? What is the in vivo function of these stem cells in the amnion? The amnion definitively needs to keep pace with the growing embryo, but is there any additional need for pluripotency? Why are stem cells readily detectable in epithelium of whole-mount and fresh term amnion but not in amniotic mesenchyme, whereas cells with stem cells capacities have been identified in cultures of amniotic mesenchyme? Why do amniotic ruptures not heal spontaneously? These are in fact just a few questions that can be addressed in the future, making use of animal models.

Non-primate models - and in particular the increasing number of mouse mutants - would enable studies on amniotic-derived stem cells, and the acquisition and maintenance of amnion plasticity.

Recently, several research groups have reported the isolation of amniotic fluid-derived and amniotic membrane-derived stem cells from rodents (De Coppi et al., 2007, Ditadi et al., 2009, Ferdaos et al., 2008, Kosuga et al., 2001, Liu et al., 2009, Marcus et al., 2008b, Nakajima et al., 2001). However, when the methodology of collection of amniotic fluid and tissue in these papers is critically reviewed, substantial inconsistencies and caveats become apparent. These inconsistencies make the identity of some - but not all - of these amniotic fluid derived and amnion-derived cells questionable.

In the study of Nakajima et al. (2001), the authors describe in detail the isolation procedure of rat amniotic membrane (E13.5E21.5), indeed emphasizing clearly the differences between the development of human and rodent extra-embryonic membranes. Kosuga et al. (2001) reported that genetically modified rat AECs injected in the brain of MPSVII mouse model showed therapeutic response with migration of the grafted cells to multiple areas of the brain and pathological improvement of these areas. It is however questionable if they worked truly with AECs because they report peeling amniotic epithelium tissue mechanically from the chorion. It is unclear which layer they have used since amnion and chorion membrane are not in physical contact in rodents.

Another extensive study was performed by Marcus and colleagues on rat amniotic stem cells. These cells carry mainly mesenchymal cell surface markers and express nanogand sox2 mRNA. They express also genes of all three germ layers, as well as telomerase. These cells can differentiate into cells of the three germ layers in vitro. In addition, the clonal analysis of the rat amnion-derived cells showed that individual clones derived from single cells were able to sustain long-term self-renewal and to undergo trilineage differentiation, confirming that the parental culture contains stem cells (Marcus et al., 2008b). After transplantation into developing fetal rat brain, the rat amnion-derived stem cells survived for a long time through adulthood without signs of tumour formation or immunological rejection. Subsets of the transplanted cells expressed vimentin and nestin, and/or attained neuronal morphology, but neuronal differentiation was not observed (Marcus et al., 2008a). Again, the actual amniotic origin of the isolated rat cells may be questioned, because of the description that the amnion was mechanically peeled from the chorion, which is not necessary in rodents since these two membranes are not in physical contact with each other. The authors emphasise the transparent and avascular nature of the murine-'amnion', hallmarks of amnion. From their description, we suppose that they may have collected the visceral yolk sac from which they peeled the avascular endoderm and the vascularized mesoderm layer. Mechanical separation of the two yolk sac layers results in two tissue layers (Fig. 5F) which resemble very much human amnion and chorion. Alternatively, Marcus and co-workers may have withdrawn the visceral yolk sac and exposed the avascular amnion.

Procedures to isolate amniotic fluid from rodents are debatable as well. De Coppi et al. (2007) reported that stem cells isolated from mouse and rat amniotic fluid closely resemble human amniotic fluid stem cells in their differentiation ability and growth capacities. The procedure to collect amniotic fluid is however poorly described. From the description it is unclear if they collected amniotic or exocoelomic fluid, the latter being much easier to collect from mice and in relative larger volumes when compared to amniotic fluid. Liu et al. (2008) transduced mouse amniotic fluid-derived stem cells with baculovirus vector. They withdrew amniotic fluid from the uterus of sacrificed E11 pregnant mice. We consider this a near to impossible procedure without ultrasound assistance of the manipulation, because the amnion encases the fetus tightly at this stage (see e.g. Fig. 3 I-J). In contrast, the collection of exocoelomic fluid would be more straightforward via this procedure. A recent study of Ditadi et al. (2009) describes the presence of c-Kit+ Lin-cells with hematopoietic potential in mouse amniotic fluid. These cells were able to generate all blood lineages in vitro, and mouse amniotic fluid derived cells differentiated to cells of all three haematopoietic lineages after transplantation in vivo. They describe "the collection of amniotic fluid samples from mouse embryos between E9.5-E19.5, after removing the maternal uterine wall to expose the amniotic sacs". It is probable that these authors may have exposed actually the visceral yolk sacs. Hence, rupture of these sacs would result in leakage of exocoelomic rather than amniotic fluid, or a mixture of both. A similar procedure was described by Ferdaos et al. (2008). The amniotic fluid was harvested with a 19-gauge needle. Again, we conclude from this description that the authors have most likely collected exocoelomic fluid.

These examples illustrate important caveats in isolation procedures and misinterpretations that are likely to result from unawareness of the profound differences between primates and rodents in the nature of their extraembryonic membranes and cavities (see above). In the context of the isolation of amniotic (fluid) derived cells, a peculiar and misleading difference between rodents and primates is definitively that primate fetuses are surrounded by large amniotic sacs, and have a relatively small yolk sac that does not surround the fetus; while the amniotic sac of rodents surrounds the fetus closely and is itself still enclosed completely by the visceral yolk sac. The latter contains the exocoelomic fluid. Moreover, the rodent amnion never fuses to the chorion. The chorion becomes incorporated completely in the chorionic plate of the placenta (Fig. 4D).

Despite the questionable origin of some of the above discussed rodent stem cells, the data illustrates that many more interesting stem cell populations may exist in extraembryonic tissues and fluids. However, the availability of molecular markers 
that are specifically expressed in e.g. amnion and not in the other extraembryonic membranes, or the respective fluids, would be extremely helpful in the comparative analysis of so-called amniotic-derived cell populations isolated by different protocols from different species.

\section{Acknowledgements \\ The authors wish to express sincere appreciation to Danny Huylebroeck for longstanding support and input, to Susana Chuva de Sousa Lopes for the many challenging discussions, to Liesbeth Lewiand Paul Vandenbergh for courtesy of Fig. 1C, to Luk Cox for courtesy of Fig. 5F, to all lab members for continuous encouragement and to Marc Missoul for animal husbandry. M.P.D. is a predoctoral fellow sponsored by VIB11, P.N.G.P. is a predoctoral fellow of FCT (SFRH/BD/15901/2005) from the GABBA program class of 2005. This work is also supported by grant $05 / 09 / 053$ from the Research Council of the University of Leuven.}

\section{References}

AKLE, C.A., ADINOLFI, M., WELSH, K.I., LEIBOWITZ, S. and MCCOLL, I. (1981). Immunogenicity of human amniotic epithelial cells after transplantation into volunteers. Lancet 2: 1003-1005.

ALVIANO, F., FOSSATI, V., MARCHIONNI, C., ARPINATI, M., BONSI, L., FRANCHINA, M., LANZONI, G., CANTONI, S., CAVALLINI, C., BIANCHI, F. et al. (2007). Term Amniotic membrane is a high throughput source for multipotent Mesenchymal Stem Cells with the ability to differentiate into endothelial cells in vitro. BMC Dev Bio/7: 11.

ANDONOVSKA, D., DZOKIC, G., SPASEVSKA, L., TRAJKOVSKA, T., POPOVSKA, K., TODOROV, I., PETROVSKI, P., KONDOV, G., SAPOVA, B., MARCIKIC, G. et al. (2008). The advantages of the application of amnion membrane in the treatment of burns. Prilozi 29: 183-198.

ANDREWS, P.W., BANTING, G., DAMJANOV, I., ARNAUD, D. and AVNER, P. (1984). Three monoclonal antibodies defining distinct differentiation antigens associated with different high molecular weight polypeptides on the surface of human embryonal carcinoma cells. Hybridoma 3: 347-361.

ARTAL, R., SOKOL, R.J., NEUMAN, M., BURSTEIN, A.H. and STOJKOV, J. (1976). The mechanical properties of prematurely and non-prematurely ruptured membranes. Methods and preliminary results. Am J Obstet Gyneco/125: 655-659.

BAILO, M., SONCINI, M., VERTUA, E., SIGNORONI, P.B., SANZONE, S., LOMBARDI, G., ARIENTI, D., CALAMANI, F., ZATTI, D., PAUL, P. et al. (2004). Engraftment potential of human amnion and chorion cells derived from term placenta. Transplantation 78: 1439-1448.

BANAS, R.A., TRUMPOWER, C., BENTLEJEWSKI, C., MARSHALL, V., SING, G. and ZEEVI, A. (2008). Immunogenicity and immunomodulatory effects of amnion-derived multipotent progenitor cells. Hum Immuno/69: 321-328.

BEDDINGTON, R.S. and ROBERTSON, E.J. (1999). Axis development and early asymmetry in mammals. Cel/96: 195-209.

BENIRSCHKE, K. and KAUFMANN, P. (1995). Pathology of the human placenta. Springer-Verlag, NY.

BIANCHI, D.W., WILKINS-HAUG, L.E., ENDERS, A.C. and HAY, E.D. (1993). Origin of extraembryonic mesoderm in experimental animals: relevance to chorionic mosaicism in humans. Am J Med Genet 46: 542-550.

BILIC, G., ZEISBERGER, S.M., MALLIK, A.S., ZIMMERMANN, R. and ZISCH, A.H. (2008). Comparative characterization of cultured human term amnion epithelial and mesenchymal stromal cells for application in cell therapy. Cell Transplant 17: 955-968.

BOGIC, L.V., BRACE, R.A. and CHEUNG, C.Y. (2000). Cellular localization of vascular endothelial growth factor in ovine placenta and fetal membranes. Placenta 21: 203-209.

BOIANI, M. and SCHOLER, H.R. (2005). Regulatory networks in embryo-derived pluripotent stem cells. Nat Rev Mol Cel/ Bio/6: 872-884.

BOURNE, G.L. (1966). The anatomy of the human amnion and chorion. Proc R Soc Med59: 1127-1128.

BRANSKI, L.K., HERNDON, D.N., CELIS, M.M., NORBURY, W.B., MASTERS,
O.E. and JESCHKE, M.G. (2008). Amnion in the treatment of pediatric partialthickness facial burns. Burns 34: 393-399.

BRIVANLOU, A.H., GAGE, F.H., JAENISCH, R., JESSELL, T., MELTON, D. and ROSSANT, J. (2003). Stem cells. Setting standards for human embryonic stem cells. Science 300: 913-916.

BRYANT-GREENWOOD, G.D. (1998). The extracellular matrix of the human fetal membranes: structure and function. Placenta 19: 1-11.

BURMAN, S., TEJWANI, S., VEMUGANTI, G.K., GOPINATHAN, U. and SANGWAN, V.S. (2004). Ophthalmic applications of preserved human amniotic membrane: a review of current indications. Cell Tissue Bank 5: 161-175.

CAI J, LI W, SU H, QIN D, YANG J, ZHU F, XU J, HE W, GUO X, LABUDA K, PETERBAUER A, WOLBANK S, ZHONG M, LI Z, WU W, SO KF, REDL H, ZENG L, ESTEBAN MA, and PEI D. (2010). Generation of human induced pluripotent stem cells from umbilical cord matrix and amniotic membrane mesenchymal cells. J Biol Chem. 285: 11227-34.

CALVIN, S.E. and OYEN, M.L. (2007). Microstructure and mechanics of the chorioamnion membrane with an emphasis on fracture properties. Ann $N Y$ Acad Sci1101: 166-185.

CHAMBERS, I., COLBY, D., ROBERTSON, M., NICHOLS, J., LEE, S., TWEEDIE, S. and SMITH, A. (2003). Functional expression cloning of Nanog, a pluripotency sustaining factor in embryonic stem cells. Cel/113: 643-655.

COUCOUVANIS, E.C., MARTIN, G.R. and NADEAU, J.H. (1995). Genetic approaches for studying programmed cell death during development of the laboratory mouse. Methods Cel/ Bio/46: 387-440.

DANSEY-BROWNING, C. (1949). On the use of amniotic membrane. BrJOphthalmol 33: 518-520.

DAVIS, J. (1910). Skin transplantation with a review of 550 cases at the Johns Hopkins Hospital. In Johns Hopkins Hospital Report, vol. 15

DE COPPI, P., BARTSCH, G., JR., SIDDIQUI, M.M., XU, T., SANTOS, C.C., PERIN, L., MOSTOSLAVSKY, G., SERRE, A.C., SNYDER, E.Y., YOO, J.J. et al. (2007). Isolation of amniotic stem cell lines with potential for therapy. Nat Biotechno/25: 100-106.

DE ROTTH, A. (1940). Plastic repair of conjuctival defects with fetal membrane. Archives of Ophthalmology 23: 522-525.

DITADI, A., DE COPPI, P., PICONE, O., GAUTREAU, L., SMATI, R., SIX, E., BONHOMME, D., EZINE, S., FRYDMAN, R., CAVAZZANA-CALVO, M. et al. (2009). Human and murine amniotic fluid c-Kit+Lin- cells display hematopoietic activity. Blood 113: 3953-3960.

DOWNS, K.M. (2008). Systematic localization of Oct-3/4 to the gastrulating mouse conceptus suggests manifold roles in mammalian development. Dev Dyn237: 464-475.

DOWNS, K.M., INMAN, K.E., JIN, D.X. and ENDERS, A.C. (2009). The Allantoic Core Domain: new insights into development of the murine allantois and its relation to the primitive streak. Dev Dyn 238: 532-553.

DUA, H.S., GOMES, J.A., KING, A.J. and MAHARAJAN, V.S. (2004). The amniotic membrane in ophthalmology. Surv Ophthalmo/49: 51-77.

ENDERS, A.C. and KING, B.F. (1988). Formation and differentiation of extraembryonic mesoderm in the rhesus monkey. Am J Anat 181: 327-340.

ENDERS, A.C., SCHLAFKE, S. and HENDRICKX, A.G. (1986). Differentiation of the embryonic disc, amnion, and yolk sac in the rhesus monkey. Am JAnat 177: 161-185.

EVANGELISTA, M., SONCINI, M. and PAROLINI, O. (2008). Placenta-derived stem cells: new hope for cell therapy? Cytotechnology 58: 33-42.

FAUZA, D. (2004). Amniotic fluid and placental stem cells. Best Pract Res Clin Obstet Gynaecol 18: 877-891.

FERDAOS, N., NATHAN, S. and NORDIN, N. (2008). Prospective full-term-derived pluripotent amniotic fluid stem (AFS) cells. Med J Malaysia 63 Suppl A: 75-76.

FOtOPOULOU, C., SEHOULI, J., GEHRMANN, N., SCHOENBORN, I. and LICHTENEGGER, W. (in press). Functional and anatomic results of amnion vaginoplasty in young women with Mayer-Rokitansky-Kuster-Hauser syndrome. Fertil Steri/DOI:10.1016/j.fertnstert.2009.01.154

FRIDENSHTEIN, A. (1982). [Stromal bone marrow cells and the hematopoietic microenvironment]. Arkh Pato/44: 3-11.

GAJIWALA, K. and GAJIWALA, A.L. (2004). Evaluation of lyophilised, gammairradiated amnion as a biological dressing. Cell Tissue Bank 5: 73-80. 
GAJIWALA, K. and LOBO GAJIWALA, A. (2003). Use of banked tissue in plastic surgery. Cell Tissue Bank 4: 141-146.

GANATRA, M.A. (2003). Amniotic membrane in surgery. J Pak Med Assoc53: 2932.

GARDNER, R.L. (1978). The relationship between cell lineage and differentiation in the early mouse embryo. Results Prob/ Cel/ Differ 9: 205-241.

GEORGE, E.L., GEORGES-LABOUESSE, E.N., PATEL-KING, R.S., RAYBURN, H. and HYNES, R.O. (1993). Defects in mesoderm, neural tube and vascular development in mouse embryos lacking fibronectin. Development 119: 10791091.

GOMES, J.A., ROMANO, A., SANTOS, M.S. and DUA, H.S. (2005). Amniotic membrane use in ophthalmology. Curr Opin Ophthalmo/16: 233-240.

GOSDEN, C.M. (1983). Amniotic fluid cell types and culture. Br Med Bul/39: 348354.

GRATACOS, E., SANIN-BLAIR, J., LEWI, L., TORAN, N., VERBIST, G., CABERO, L. and DEPREST, J. (2006). A histological study of fetoscopic membrane defects to document membrane healing. Placenta 27: 452-456.

GRISAFI, D., PICCOLI, M., POZZOBON, M., DITADI, A., ZARAMELLA, P., CHIANDETTI, L., ZANON, G.F., ATALA, A., ZACCHELLO, F., SCARPA, M. et al. (2008). High transduction efficiency of human amniotic fluid stem cells mediated by adenovirus vectors. Stem Cells Dev 17: 953-962.

GRUETERICH, M., ESPANA, E.M. and TSENG, S.C. (2003). Ex vivo expansion of limbal epithelial stem cells: amniotic membrane serving as a stem cell niche. Surv Ophthalmo/48: 631-646.

GRUSS, J.S. and JIRSCH, D.W. (1978). Human amniotic membrane: a versatile wound dressing. Can Med Assoc J 118: 1237-1246.

GULLER, S., KONG, L., WOZNIAK, R. and LOCKWOOD, C.J. (1995). Reduction of extracellular matrix protein expression in human amnion epithelial cells by glucocorticoids: a potential role in preterm rupture of the fetal membranes. J Clin Endocrinol Metab 80: 2244-2250.

HAN, Y.M., ROMERO, R., KIM, J.S., TARCA, A.L., KIM, S.K., DRAGHICI, S., KUSANOVIC, J.P., GOTSCH, F., MITTAL, P., HASSAN, S.S. et al. (2008). Region-specific gene expression profiling: novel evidence for biological heterogeneity of the human amnion. Biol Reprod79: 954-961.

HAO, Y., MA, D.H., HWANG, D.G., KIM, W.S. and ZHANG, F. (2000). Identification of antiangiogenic and antiinflammatory proteins in human amniotic membrane. Cornea 19: 348-352.

HASEGAWA, M., FUJISAWA, H., HAYASHI, Y. and YAMASHITA, J. (2004). Autologous amnion graft for repair of myelomeningocele: technical note and clinical implication. J Clin Neurosci 11: 408-411.

HERTIG, A.T. and ROCK, J. (1949). Two human ova of the pre-villous stage, having a developmental age of about 8 and 9 days respectively. Contrib Embryo/33: 169-186.

HEUSER, C.H. and STREETER, G.L. (1941). Development of the macaque embryo. Contributions to Embryology 29: 15-55.

HIGA, K., SHIMMURA, S., SHIMAZAKI, J. and TSUBOTA, K. (2005). Hyaluronic acid-CD44 interaction mediates the adhesion of lymphocytes by amniotic membrane stroma. Cornea 24: 206-212.

HILL, J.P. (1932). The developmental history of the primates. Philosophical Transactions of the Royal Society of London, Series B: Biological Sciences 221: 45178.

HORI, J., WANG, M., KAMIYA, K., TAKAHASHI, H. and SAKURAGAWA, N. (2006). Immunological characteristics of amniotic epithelium. Cornea 25: S53-58.

HORWITZ, E.M., LE BLANC, K., DOMINICI, M., MUELLER, I., SLAPERCORTENBACH, I., MARINI, F.C., DEANS, R.J., KRAUSE, D.S. and KEATING, A. (2005). Clarification of the nomenclature for MSC: The International Society for Cellular Therapy position statement. Cytotherapy 7: 393-395.

ILANCHERAN, S., MICHALSKA, A., PEH, G., WALLACE, E.M., PERA, M. and MANUELPILLAI, U. (2007). Stem cells derived from human fetal membranes display multilineage differentiation potential. Biol Reprod 77: 577-588.

ILANCHERAN, S., MOODLEY, Y. and MANUELPILLAI, U. (2009). Human fetal membranes: a source of stem cells for tissue regeneration and repair? Placenta 30: 2-10.

INSAUSTICL, BLANQUER M, BLEDA P, INIESTA P, MAJADO MJ, CASTELLANOS
G, and MORALEDA JM. (2010). The amniotic membrane as a source of stem cells. Histol Histopathol. 25:91-8.

IN 'T ANKER, P.S., SCHERJON, S.A., KLEIJBURG-VAN DER KEUR, C., NOORT, W.A., CLAAS, F.H., WILLEMZE, R., FIBBE, W.E. and KANHAI, H.H. (2003). Amniotic fluid as a novel source of mesenchymal stem cells for therapeutic transplantation. Blood 102: 1548-1549.

JAENISCH, R. and YOUNG, R. (2008). Stem cells, the molecular circuitry of pluripotency and nuclear reprogramming. Cel/132: 567-582.

JIANG, Y., JAHAGIRDAR, B.N., REINHARDT, R.L., SCHWARTZ, R.E., KEENE, C.D., ORTIZ-GONZALEZ, X.R., REYES, M., LENVIK, T., LUND, T. BLACKSTAD, M. etal. (2002). Pluripotency of mesenchymal stem cells derived from adult marrow. Nature 418: 41-49.

KAKISHITA, K., ELWAN, M.A., NAKAO, N., ITAKURA, T. and SAKURAGAWA, N. (2000). Human amniotic epithelial cells produce dopamine and survive after implantation into the striatum of a rat model of Parkinson's disease: a potential source of donor for transplantation therapy. Exp Neuro/ 165: 27-34.

KAKISHITA, K., NAKAO, N., SAKURAGAWA, N. and ITAKURA, T. (2003). Implantation of human amniotic epithelial cells prevents the degeneration of nigral dopamine neurons in rats with 6-hydroxydopamine lesions. Brain Res 980: 4856.

KANNAGI, R., COCHRAN, N.A., ISHIGAMI, F., HAKOMORI, S., ANDREWS, P.W., KNOWLES, B.B. and SOLTER, D. (1983). Stage-specific embryonic antigens (SSEA-3 and -4) are epitopes of a unique globo-series ganglioside isolated from human teratocarcinoma cells. EMBO J2: 2355-2361.

KANYSHKOVA, T.G., BUNEVA, V.N. and NEVINSKY, G.A. (2001). Lactoferrin and its biological functions. Biochemistry (Mosc) 66: 1-7.

KAUFMAN, M.H. (1992). The Atlas of Mouse Development. Academic Press, CA.

KAVIANI, A., PERRY, T.E., DZAKOVIC, A., JENNINGS, R.W., ZIEGLER, M.M. and FAUZA, D.O. (2001). The amniotic fluid as a source of cells for fetal tissue engineering. J Pediatr Surg 36: 1662-1665.

KEELAN, J.A., ZHOU, R.L. and MITCHELL, M.D. (2000). Activin A exerts both proand anti-inflammatory effects on human term gestational tissues. Placenta21: 38-43.

KESTING, M.R., WOLFF, K.D., HOHLWEG-MAJERT, B. and STEINSTRAESSER, L. (2008). The role of allogenic amniotic membrane in burn treatment. J Burn Care Res 29: 907-916.

KIM, J., LEE, Y., KIM, H., HWANG, K.J., KWON, H.C., KIM, S.K., CHO, D.J., KANG, S.G. and YOU, J. (2007). Human amniotic fluid-derived stem cells have characteristics of multipotent stem cells. Cell Prolif 40: 75-90.

KIM, J.C. and TSENG, S.C. (1995). Transplantation of preserved human amniotic membrane for surface reconstruction in severely damaged rabbit corneas. Cornea 14: 473-484.

KIM, J.S., KIM, J.C., NA, B.K., JEONG, J.M. and SONG, C.Y. (2000). Amniotic membrane patching promotes healing and inhibits proteinase activity on wound healing following acute corneal alkali burn. Exp Eye Res 70: 329-337.

KIM, J.Y., CHOI, Y.M., JEONG, S.W. and WILLIAMS, D.L. (2009). Effect of bovine freeze-dried amniotic membrane (Amnisite-BA) on uncomplicated canine corneal erosion. Vet Ophthalmo/12: 36-42.

KINDER, S.J., TSANG, T.E., QUINLAN, G.A., HADJANTONAKIS, A.K., NAGY, A and TAM, P.P. (1999). The orderly allocation of mesodermal cells to the extraembryonic structures and the anteroposterior axis during gastrulation of the mouse embryo. Development 126: 4691-4701.

KING, B.F. (1980). Developmental changes in the fine structure of rhesus monkey amnion. Am J Anat 157: 285-307.

KOBAYASHI, A., SUGIYAMA, K., LI, W. and TSENG, S.C. (2008a). In vivolaser confocal microscopy findings of cryopreserved and fresh human amniotic membrane. Ophthalmic Surg Lasers Imaging 39: 312-318.

KOBAYASHI, M., YAKUWA, T., SASAKI, K., SATO, K., KIKUCHI, A., KAMO, I. YOKOYAMA, Y. and SAKURAGAWA, N. (2008b). Multilineage potential of side population cells from human amnion mesenchymal layer. Cell Transplant 17: 291-301.

KOLAMBKAR, Y.M., PEISTER, A., SOKER, S., ATALA, A. and GULDBERG, R.E. (2007). Chondrogenic differentiation of amniotic fluid-derived stem cells. J Mol Histo/38: 405-413.

KONG, X.Y., CAI, Z., PAN, L., ZHANG, L., SHU, J., DONG, Y.L., YANG, N., LI, Q. HUANG, X.J. and ZUO, P.P. (2008). Transplantation of human amniotic cells 
exerts neuroprotection in MPTP-induced Parkinson disease mice. Brain Res 1205: 108-115.

KOSUGA, M., SASAKI, K., TANABE, A., LI, X.K., OKAWA, H., OGINO, I., OKUDA, O., ARAI, H., SAKURAGAWA, N., KAMATA, Y. et al. (2001). Engraftment of genetically engineered amniotic epithelial cells corrects lysosomal storage in multiple areas of the brain in mucopolysaccharidosis type VII mice. Mol Ther3: 139-148.

KRUSE, F.E. and CURSIEFEN, C. (2008). Surgery of the cornea: corneal, limbal stem cell and amniotic membrane transplantation. Dev Ophthalmo/41: 159170.

KUBO, M., SONODA, Y., MURAMATSU, R. and USUI, M. (2001). Immunogenicity of human amniotic membrane in experimental xenotransplantation. Invest Ophthalmol Vis Sci42: 1539-1546.

LAWSON, K.A., MENESES, J.J. and PEDERSEN, R.A. (1991). Clonal analysis of epiblast fate during germ layer formation in the mouse embryo. Development 113: 891-911.

LEI, H., FURTH, E.E., KALLURI, R., CHIOU, T., TILLY, K.I., TILLY, J.L., ELKON, K.B., JEFFREY, J.J. and STRAUSS, J.F., 3RD. (1996). A program of cell death and extracellular matrix degradation is activated in the amnion before the onset of labor. J Clin Invest 98: 1971-1978.

LEI, H., KALLURI, R., FURTH, E.E., BAKER, A.H. and STRAUSS, J.F., 3RD. (1999). Rat amnion type IV collagen composition and metabolism: implications for membrane breakdown. Biol Reprod 60: 176-182.

LEWI, L., VAN SCHOUBROECK, D., VAN RANST, M., BRIES, G., EMONDS, M.P., ARABIN, B., WELCH, R. and DEPREST, J. (2004). Successful patching of iatrogenic rupture of the fetal membranes. Placenta 25: 352-356.

LI, H., NIEDERKORN, J.Y., NEELAM, S., MAYHEW, E., WORD, R.A., MCCULLEY, J.P. and ALIZADEH, H. (2005). Immunosuppressive factors secreted by human amniotic epithelial cells. Invest Ophthalmol Vis Sci46: 900-907.

LI, W., HE, H., CHEN, Y.T., HAYASHIDA, Y. and TSENG, S.C. (2008). Reversal of myofibroblasts by amniotic membrane stromal extract. J Cell Physio/215: 657664.

LI, W., HE, H., KAWAKITA, T., ESPANA, E.M. and TSENG, S.C. (2006). Amniotic membrane induces apoptosis of interferon-gamma activated macrophages in vitro. Exp Eye Res 82: 282-292.

LIU, Z.S., XU, Y.F., FENG, S.W., LI, Y., YAO, X.L., LU, X.L. and ZHANG, C. (2009). Baculovirus-transduced mouse amniotic fluid-derived stem cells maintain differentiation potential. Ann Hemato/88: 565-572.

LUCKETT, W.P. (1975). The development of primordial and definitive amniotic cavities in early Rhesus monkey and human embryos. Am J Anat 144: 149-167.

LUCKETT, W.P. (1978). Origin and differentiation of the yolk sac and extraembryonic mesoderm in presomite human and rhesus monkey embryos. Am J Anat 152: 59-97.

MADHIRA, S.L., VEMUGANTI, G., BHADURI, A., GADDIPATI, S., SANGWAN, V.S. and GHANEKAR, Y. (2008). Culture and characterization of oral mucosal epithelial cells on human amniotic membrane for ocular surface reconstruction. Mol Vis 14: 189-196.

MAGATTI, M., DE MUNARI, S., VERTUA, E., GIBELLI, L., WENGLER, G.S. and PAROLINI, O. (2008). Human amnion mesenchyme harbors cells with allogeneic T-cell suppression and stimulation capabilities. Stem Cells 26: 182-192.

MAHGOUB, M.A., AMMAR, A., FAYEZ, M., EDRIS, A., HAZEM, A., AKL, M. and HAMMAM, O. (2004). Neovascularization of the amniotic membrane as a biological immune barrier. Transplant Proc 36: 1194-1198.

MALAK, T.M. and BELL, S.C. (1994). Structural characteristics of term human fetal membranes: a novel zone of extreme morphological alteration within the rupture site. Br J Obstet Gynaecol101: 375-386.

MALLIK, A.S., FICHTER, M.A., RIEDER, S., BILIC, G., STERGIOULA, S., HENKE, J., SCHNEIDER, K.T., KURMANAVICIUS, J., BIEMER, E., ZIMMERMANN, R. et al. (2007). Fetoscopic closure of punctured fetal membranes with acellular human amnion plugs in a rabbit model. Obstet Gyneco/110: 1121-1129.

MARCUS, A.J., COYNE, T.M., BLACK, I.B. and WOODBURY, D. (2008a). Fate of amnion-derived stem cells transplanted to the fetal rat brain: migration, survival and differentiation. J Cel/ Mol Med 12: 1256-1264.

MARCUS, A.J., COYNE, T.M., RAUCH, J., WOODBURY, D. and BLACK, I.B. (2008b). Isolation, characterization, and differentiation of stem cells derived from the rat amniotic membrane. Differentiation 76: 130-144.
MARCUS, A.J. and WOODBURY, D. (2008). Fetal stem cells from extra-embryonic tissues: do not discard. J Cel/ Mol Med 12: 730-742.

MELLER, D., PIRES, R.T., MACK, R.J., FIGUEIREDO, F., HEILIGENHAUS, A., PARK, W.C., PRABHASAWAT, P., JOHN, T., MCLEOD, S.D., STEUHL, K.P. et al. (2000). Amniotic membrane transplantation for acute chemical or thermal burns. Ophthalmology 107: 980-990.

MENG, X.T., LI, C., DONG, Z.Y., LIU, J.M., LI, W., LIU, Y., XUE, H. and CHEN, D. (2008). Co-transplantation of bFGF-expressing amniotic epithelial cells and neural stem cells promotes functional recovery in spinal cord-injured rats. Cell Biol Int 32: 1546-1558.

MIGNATTI, P., TSUBOI, R., ROBBINS, E. and RIFKIN, D.B. (1989). In vitro angiogenesis on the human amniotic membrane: requirement for basic fibroblast growth factor-induced proteinases. $J$ Cell Bio/108: 671-682.

MIKI, T., LEHMANN, T., CAI, H., STOLZ, D.B. and STROM, S.C. (2005). Stem cell characteristics of amniotic epithelial cells. Stem Cells 23: 1549-1559.

MIKI, T., MITAMURA, K., ROSS, M.A., STOLZ, D.B. and STROM, S.C. (2007). Identification of stem cell marker-positive cells by immunofluorescence in term human amnion. J Reprod Immuno/75: 91-96.

MIKI, T. and STROM, S.C. (2006). Amnion-derived pluripotent/multipotent stem cells. Stem Cell Rev2: 133-142.

MIKI T, MARONGIU F, DORKO K, ELLIS EC, and STROM SC. (2010). Isolation of amniotic epithelial stem cells. Curr Protoc Stem Cell Biol. Chapter 1:Unit 1E.3.

NAKAJIMA, T., ENOSAWA, S., MITANI, T., LI, X.K., SUZUKI, S., AMEMIYA, H., KOIWAI, O. and SAKURAGAWA, N. (2001). Cytological examination of rat amniotic epithelial cells and cell transplantation to the liver. Cell Transplant 10: 423-427.

NAKAMA, H., OHSUGI, K., OTSUKI, T., DATE, I., KOSUGA, M., OKUYAMA, T. and SAKURAGAWA, N. (2006). Encapsulation cell therapy for mucopolysaccharidosis type VII using genetically engineered immortalized human amniotic epithelial cells. Tohoku J Exp Med209: 23-32.

NICHOLS, J., ZEVNIK, B., ANASTASSIADIS, K., NIWA, H., KLEWE-NEBENIUS, D., CHAMBERS, I., SCHOLER, H. and SMITH, A. (1998). Formation of pluripotent stem cells in the mammalian embryo depends on the POU transcription factor Oct4. Cel/95: 379-391.

NIKNEJAD, H., PEIROVI, H., JORJANI, M., AHMADIANI, A., GHANAVI, J. and SEIFALIAN, A.M. (2008). Properties of the amniotic membrane for potential use in tissue engineering. Eur Cell Mater 15: 88-99.

NIKNEJAD H, PEIROVI H, AHMADIANI A, GHANAVI J, and JORJANI M. (2010). Differentiation factors that influence neuronal markers expression in vitro from human amniotic epithelial cells. Eur Cell Mater. 19:22-9.

NUBILE, M., DUA, H.S., LANZINI, T.E., CARPINETO, P., CIANCAGLINI, M., TOTO, L. and MASTROPASQUA, L. (2008). Amniotic membrane transplantation for the management of corneal epithelial defects: an in vivo confocal microscopic study. Br J Ophthalmo/92: 54-60.

OCHSENBEIN-KOLBLE, N., JANI, J., LEWI, L., VERBIST, G., VERCRUYSSE, L., PORTMANN-LANZ, B., MARQUARDT, K., ZIMMERMANN, R. and DEPREST, J. (2007). Enhancing sealing of fetal membrane defects using tissue engineered native amniotic scaffolds in the rabbit model. Am J Obstet Gyneco/196: 263 e17.

OKAWA, H., OKUDA, O., ARAI, H., SAKURAGAWA, N. and SATO, K. (2001). Amniotic epithelial cells transform into neuron-like cells in the ischemic brain. Neuroreport 12: 4003-4007.

ONO, K., YOKOO, S., MIMURA, T., USUI, T., MIYATA, K., ARAIE, M., YAMAGAMI, S. and AMANO, S. (2007). Autologous transplantation of conjunctival epithelial cells cultured on amniotic membrane in a rabbit model. Mol Vis 13: 1138-1143.

OSWALD, J., BOXBERGER, S., JORGENSEN, B., FELDMANN, S., EHNINGER, G., BORNHAUSER, M. and WERNER, C. (2004). Mesenchymal stem cells can be differentiated into endothelial cells in vitro. Stem Cells 22: 377-384.

PALIS, J., MCGRATH, K.E. and KINGSLEY, P.D. (1995). Initiation of hematopoiesis and vasculogenesis in murine yolk sac explants. Blood 86: 156-163.

PAN, H.C., CHIN, C.S., YANG, D.Y., HO, S.P., CHEN, C.J., HWANG, S.M., CHANG, M.H. and CHENG, F.C. (2009). Human amniotic fluid mesenchymal stem cells in combination with hyperbaric oxygen augment peripheral nerve regeneration. Neurochem Res 34: 1304-1316.

PAPPA, K.I. and ANAGNOU, N.P. (2009). Novel sources of fetal stem cells: where do they fit on the developmental continuum? Regen Med 4: 423-433. 
PAROLINI, O., ALVIANO, F., BAGNARA, G.P., BILIC, G., BUHRING, H.J., EVANGELISTA, M., HENNERBICHLER, S., LIU, B., MAGATTI, M., MAO, N. et al. (2008). Concise review: isolation and characterization of cells from human term placenta: outcome of the first international Workshop on Placenta Derived Stem Cells. Stem Cells 26: 300-311.

PAROLINI, O., SONCINI, M., EVANGELISTA, M. and SCHMIDT, D. (2009). Amniotic membrane and amniotic fluid-derived cells: potential tools for regenerative medicine? Regen Med 4: 275-291.

PARRY, S. and STRAUSS, J.F., 3RD. (1998). Premature rupture of the fetal membranes. N Eng/J Med 338: 663-670.

PASQUINELLI, G., TAZZARI, P., RICCI, F., VASELLI, C., BUZZI, M., CONTE, R., ORRICO, C., FORONI, L., STELLA, A., ALVIANO, F. et al. (2007). Ultrastructural characteristics of human mesenchymal stromal (stem) cells derived from bone marrow and term placenta. Ultrastruct Patho/31: 23-31.

PERIN, L., GIULIANI, S., JIN, D., SEDRAKYAN, S., CARRARO, G., HABIBIAN, R., WARBURTON, D., ATALA, A. and DE FILIPPO, R.E. (2007). Renal differentiation of amniotic fluid stem cells. Cell Prolif 40: 936-948.

PRUSA, A.R. and HENGSTSCHLAGER, M. (2002). Amniotic fluid cells and human stem cell research: a new connection. Med Sci Monit 8: RA253-257.

PRUSA, A.R., MARTON, E., ROSNER, M., BERNASCHEK, G. and HENGSTSCHLAGER, M. (2003). Oct-4-expressing cells in human amniotic fluid: a new source for stem cell research? Hum Reprod 18: 1489-1493.

RAVISHANKER, R., BATH, A.S. and ROY, R. (2003). «Amnion Bank»-the use of long term glycerol preserved amniotic membranes in the management of superficial and superficial partial thickness burns. Burns 29: 369-374.

ROBINSON, W.P., MCFADDEN, D.E., BARRETT, I.J., KUCHINKA, B., PENAHERRERA, M.S., BRUYERE, H., BEST, R.G., PEDREIRA, D.A., LANGLOIS, S. and KALOUSEK, D.K. (2002). Origin of amnion and implications for evaluation of the fetal genotype in cases of mosaicism. Prenat Diagn 22: 1076-1085

ROBSON, M.C. and KRIZEK, T.J. (1973). The effect of human amniotic membranes on the bacteria population of infected rat burns. Ann Surg 177: 144-149.

ROBSON, M.C., SAMBURG, J.L. and KRIZEK, T.J. (1973). Quantitative comparison of biological dressings. J Surg Res 14: 431-434.

RODRIGUEZ-ARES, M.T., TOURINO, R., LOPEZ-VALLADARES, M.J. and GUDE, F. (2004). Multilayer amniotic membrane transplantation in the treatment of corneal perforations. Cornea 23: 577-583.

ROUBELAKIS, M.G., PAPPA, K.I., BITSIKA, V., ZAGOURA, D., VLAHOU, A., PAPADAKI, H.A., ANTSAKLIS, A. and ANAGNOU, N.P. (2007). Molecular and proteomic characterization of human mesenchymal stem cells derived from amniotic fluid: comparison to bone marrow mesenchymal stem cells. Stem Cells Dev 16: 931-952.

SABELLA, N. (1913). Use of fetal membranes in skin grafting. Med Rec NY83: 478.

SAKURAGAWA, N., ENOSAWA, S., ISHII, T., THANGAVEL, R., TASHIRO, T., OKUYAMA, T. and SUZUKI, S. (2000). Human amniotic epithelial cells are promising transgene carriers for allogeneic cell transplantation into liver. J Hum Genet 45: 171-176.

SAKURAGAWA, N., KAKINUMA, K., KIKUCHI, A., OKANO, H., UCHIDA, S., KAMO, I., KOBAYASHI, M. and YOKOYAMA, Y. (2004). Human amnion mesenchyme cells express phenotypes of neuroglial progenitor cells. JNeurosC Res 78: 208-214.

SAKURAGAWA, N., THANGAVEL, R., MIZUGUCHI, M., HIRASAWA, M. and KAMO, I. (1996). Expression of markers for both neuronal and glial cells in human amniotic epithelial cells. Neurosci Lett 209: 9-12.

SANGWAN, V.S., BURMAN, S., TEJWANI, S., MAHESH, S.P. and MURTHY, R. (2007). Amniotic membrane transplantation: a review of current indications in the management of ophthalmic disorders. Indian J Ophthalmo/55: 251-260.

SANKAR, V. and MUTHUSAMY, R. (2003). Role of human amniotic epithelial cell transplantation in spinal cord injury repair research. Neuroscience 118: 11-17.

SCHMIDT, W. (1992). The amniotic fluid compartment: the fetal habitat. Adv Anat Embryol Cell Biol 127: 1-100.

SCOTT, J.N., REAM, L.J. and PENDERGRASS, P.B. (1982). Developmental changes in the mouse amnion: a SEM study. J Submicrosc Cyto/14: 607-612.

SIEGEL, N., ROSNER, M., HANNEDER, M., FREILINGER, A. and HENGSTSCHLAGER, M. (2008). Human amniotic fluid stem cells: a new perspective. Amino Acids 35: 291-293.

SIMAT, S.F., CHUA, K.H., ABDUL RAHMAN, H., TAN, A.E. and TAN, G.C. (2008) The stemness gene expression of cultured human amniotic epithelial cells in serial passages. Med J Malaysia 63 Suppl A: 53-54.

SINGH, R., CHOUHAN, U.S., PUROHIT, S., GUPTA, P., KUMAR, P., KUMAR, A., CHACHARKAR, M.P., KACHHAWA, D. and GHIYA, B.C. (2004). Radiation processed amniotic membranes in the treatment of non-healing ulcers of different etiologies. Cell Tissue Bank 5: 129-134.

SINGH, R., KUMAR, D., KUMAR, P. and CHACHARKAR, M.P. (2008). Development and evaluation of silver-impregnated amniotic membrane as an antimicrobial burn dressing. J Burn Care Res 29: 64-72.

SINGH, R., PUROHIT, S., CHACHARKAR, M.P., BHANDARI, P.S. and BATH, A.S (2007). Microbiological safety and clinical efficacy of radiation sterilized amniotic membranes for treatment of second-degree burns. Burns 33: 505-510.

SIPPEL, K.C., MA, J.J. and FOSTER, C.S. (2001). Amniotic membrane surgery. Curr Opin Ophthalmo/12: 269-281.

SMITH, J.L., GESTELAND, K.M. and SCHOENWOLF, G.C. (1994). Prospective fate map of the mouse primitive streak at 7.5 days of gestation. Dev Dyn 201: 279-289.

SNELL, G.D. and STEVENS, L.C. (1966). Early embryology in Biology of the laboratory mouse. Dover Publications, NY.

SONCINI, M., VERTUA, E., GIBELLI, L., ZORZI, F., DENEGRI, M., ALBERTINI, A WENGLER, G.S. and PAROLINI, O. (2007). Isolation and characterization of mesenchymal cells from human fetal membranes. J Tissue Eng Regen Med 1 : 296-305.

SORSBY, A., HAYTHORNE, J. and REED, H. (1947). Further Experience with Amniotic Membrane Grafts in Caustic Burns of the Eye. Br J Ophthalmo/31: 409-418.

SORSBY, A. and SYMONS, H.M. (1946). AMNIOTIC MEMBRANE GRAFTS IN CAUSTIC BURNS OF THE EYE: (Burns of the second degree). BrJ Ophthalmol 30: $337-345$

SUDHA, B., SITALAKSHMI, G., IYER, G.K. and KRISHNAKUMAR, S. (2008) Putative stem cell markers in limbal epithelial cells cultured on intact \& denuded human amniotic membrane. Indian J Med Res 128: 149-156.

TAKAHASHI, K. and YAMANAKA, S. (2006). Induction of pluripotent stem cells from mouse embryonic and adult fibroblast cultures by defined factors. Cel/126: 663-676

TAKAHASHI, S., OHSUGI, K., YAMAMOTO, T., SHIOMI, M. and SAKURAGAWA, N. (2001). A novel approach to ex vivo gene therapy for familial hypercholesterolemia using human amniotic epithelial cells as a transgene carrier. Tohoku $J$ Exp Med 193: 279-292.

TAKASHIMA, S., ISE, H., ZHAO, P., AKAIKE, T. and NIKAIDO, T. (2004). Human amniotic epithelial cells possess hepatocyte-like characteristics and functions. Cell Struct Funct 29: 73-84.

TAKASHIMA, S., YASUO, M., SANZEN, N., SEKIGUCHI, K., OKABE, M., YOSHIDA, T., TODA, A. and NIKAIDO, T. (2008). Characterization of laminin isoforms in human amnion. Tissue Cel/40: 75-81.

TAM, P.P. and BEDDINGTON, R.S. (1987). The formation of mesodermal tissues in the mouse embryo during gastrulation and early organogenesis. Development 99: 109-126.

TAM, P.P. and BEDDINGTON, R.S. (1992). Establishment and organization of germ layers in the gastrulating mouse embryo. Ciba Found Symp 165: 27-41; discussion $42-49$

TAM, P.P. and LOEBEL, D.A. (2007). Gene function in mouse embryogenesis: get set for gastrulation. Nat Rev Genet 8: 368-381.

TAMAGAWA, T., ISHIWATA, I. and SAITO, S. (2004). Establishment and characterization of a pluripotent stem cell line derived from human amniotic membranes and initiation of germ layers in vitro. Hum Cel/ 17: 125-130.

TAMAGAWA, T., OI, S., ISHIWATA, I., ISHIKAWA, H. and NAKAMURA, Y. (2007). Differentiation of mesenchymal cells derived from human amniotic membranes into hepatocyte-like cells in vitro. Hum Cel/20: 77-84.

TODA, A., OKABE, M., YOSHIDA, T. and NIKAIDO, T. (2007). The potential of amniotic membrane/amnion-derived cells for regeneration of various tissues. $J$ Pharmacol Sci 105: 215-228.

TOSI, G.M., MASSARO-GIORDANO, M., CAPOROSSI, A. and TOTI, P. (2005) 
Amniotic membrane transplantation in ocular surface disorders. $J$ Cell Physiol 202: 849-851.

TSAI, M.S., HWANG, S.M., CHEN, K.D., LEE, Y.S., HSU, L.W., CHANG, Y.J., WANG, C.N., PENG, H.H., CHANG, Y.L., CHAO, A.S. et al. (2007). Functional network analysis of the transcriptomes of mesenchymal stem cells derived from amniotic fluid, amniotic membrane, cord blood, and bone marrow. Stem Cells 25: 2511-2523

TSAI, M.S., LEE, J.L., CHANG, Y.J. and HWANG, S.M. (2004). Isolation of human multipotent mesenchymal stem cells from second-trimester amniotic fluid using a novel two-stage culture protocol. Hum Reprod 19: 1450-1456.

TSENG, S.C., PRABHASAWAT, P., BARTON, K., GRAY, T. and MELLER, D. (1998). Amniotic membrane transplantation with or without limbal allografts for corneal surface reconstruction in patients with limbal stem cell deficiency. Arch Ophthalmo/116: 431-441.

TSENG, S.C., PRABHASAWAT, P. and LEE, S.H. (1997). Amniotic membrane transplantation for conjunctival surface reconstruction. Am J Ophthalmo/124: 765-774.

VAN HERENDAEL, B.J., OBERTI, C. and BROSENS, I. (1978). Microanatomy of the human amniotic membranes. A light microscopic, transmission, and scanning electron microscopic study. Am J Obstet Gyneco/131: 872-880.

WEI, J.P., ZHANG, T.S., KAWA, S., AIZAWA, T., OTA, M., AKAIKE, T., KATO, K., KONISHI, I. and NIKAIDO, T. (2003). Human amnion-isolated cells normalize blood glucose in streptozotocin-induced diabetic mice. Cell Transp/12: 545552.

WILSHAW, S.P., KEARNEY, J., FISHER, J. and INGHAM, E. (2008). Biocompatibility and potential of acellular human amniotic membrane to support the attachment and proliferation of allogeneic cells. Tissue Eng Part A 14: 463-472.

WOLBANK, S., PETERBAUER, A., FAHRNER, M., HENNERBICHLER, S., VAN
GRIENSVEN, M., STADLER, G., REDL, H. and GABRIEL, C. (2007). Dosedependent immunomodulatory effect of human stem cells from amniotic membrane: a comparison with human mesenchymal stem cells from adipose tissue. Tissue Eng 13: 1173-1183.

WOLBANK, S., STADLER, G., PETERBAUER, A., GILLICH, A., KARBIENER, M., STREUBEL, B., WIESER, M., KATINGER, H., VAN GRIENSVEN, M., REDL, H. et al. (2009). Telomerase immortalized human amnion- and adipose-derived mesenchymal stem cells: maintenance of differentiation and immunomodulatory characteristics. Tissue Eng Part A 15: 1843-1854.

WU, Z.Y., HUI, G.Z., LU, Y., WU, X. and GUO, L.H. (2006). Transplantation of human amniotic epithelial cells improves hindlimb function in rats with spinal cord injury. Chin Med J (Engl) 119: 2101-2107.

$\mathrm{XU}$, P., ALFAIDY, N. and CHALLIS, J.R. (2002). Expression of matrix metalloproteinase (MMP)-2 and MMP-9 in human placenta and fetal membranes in relation to preterm and term labor. J Clin Endocrinol Metab87: 13531361.

YOU, Q., CAI, L., ZHENG, J., TONG, X., ZHANG, D. and ZHANG, Y. (2008) Isolation of human mesenchymal stem cells from third-trimester amniotic fluid. Int J Gynaecol Obstet 103: 149-152.

ZHAO, P., ISE, H., HONGO, M., OTA, M., KONISHI, I. and NIKAIDO, T. (2005) Human amniotic mesenchymal cells have some characteristics of cardiomyocytes. Transplantation 79: 528-535.

ZHENG, Y.B., GAO, Z.L., XIE, C., ZHU, H.P., PENG, L., CHEN, J.H. and CHONG Y.T. (2008). Characterization and hepatogenic differentiation of mesenchymal stem cells from human amniotic fluid and human bone marrow: a comparative study. Cell Biol Int 32: 1439-1448.

ZHOU, S., CHEN, J. and FENG, J. (2003). The effects of amniotic membrane on polymorphonuclear cells. Chin Med J (Engl) 116: 788-790. 


\section{Further Related Reading, published previously in the Int. J. Dev. Biol.}

See Special Issue Pattern Formation edited by Michael K. Richardson and Cheng-Ming Chuong at:

http://www.ijdb.ehu.es/web/contents.php?vol=53\&issue=5-6

Role of fetal membranes in signaling of fetal maturation and parturition Leslie Myatt and Kang Sun

Int. J. Dev. Biol. (2010) 54: 545-553

Amniotic fluid induces rapid epithelialization in the experimentally ruptured fetal mouse palate - implications for fetal wound healing

Toshiya Takigawa and Kohei Shiota

Int. J. Dev. Biol. (2007) 51: 67-77

Tumor necrosis factor in the human fetoplacentary unit

E Saksela and M Jäättelä

Int. J. Dev. Biol. (1989) 33: 173-176

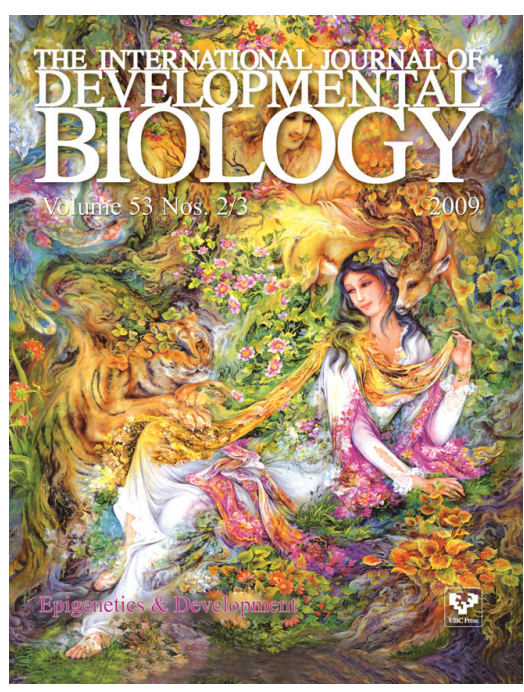

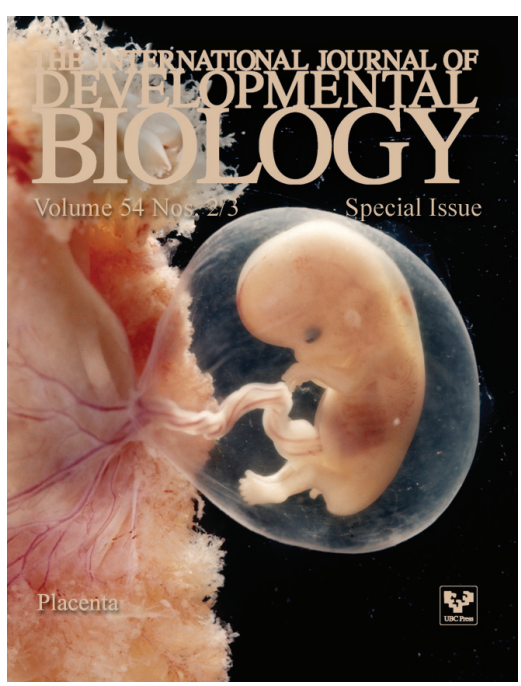

5 yr ISI Impact Factor $(2008)=3.271$ 